\title{
LA ESTRUCTURA DE LAS RELACIONES DE PRODUCCIÓN TRIBUTARIAS: ESTADO Y SOCIEDAD EN BIZANCIO Y EL ISLAM PRIMITIVO
}

por

\author{
JOHN HALDON \\ Universidad de Birmingham.
}

RESUMEN: Este artículo analiza el valor del concepto de modo de producción tributario en relación a dos configuraciones estatales y socio-politicas concretas, la del Imperio Bizantino por una parte, y la temprana califal unificada de los Omeyas y primeros 'Abbāsies por olra. Si bien se argumenta que el analisis de las formaciones sociales a escala del modo de producción puede ayudar a poner en evidencia los elementos claves en las relaciones de producción y distribución del excedente permitiendo así enfocar la discusión bistórica sobre las estructuras fundamentales que determinan el acceso al poder politico y económico o a la autoridad en cualguier formación social, el articulo también muestra que una mayor precisión en el análisis dependerá de la discusión, a escala de las propias formaciones sociales, de las relaciones políticas de redistribución del excedente, lo que determina en gran medida las instituciones socio-económicas de la sociedad y el estado en cuestión, asi como los limites impuestos sobre estas relaciones politicas por las estructuras económicas que los sustentan.

PALABRAS CLAVE: Edad Media, Imperio Bizantino, Islam temprano, Modo de Producción, Formaciones Sociales.

ABSTRACT: This paper examines the value of the concept of a tributary mode of production in relation to two sperific state and socio political configurations, the East Roman or Byzantine Empire, on the one band, and the early unified caliphate of the Umayyads and the 'Abbassids on the other. While arguing that analysis of social formations at the level of mode of production can asist in pinpointing key elements in the relations of production and distribution of surplues wealth, and tbus focusing bistorical discussion on the fundamental structures which determined access to political and economic power and authority in any given social formation, this paper also notes that further refinement of the analysis will depend upon discussion, at the level of social formation, of the political relations of surplus redistribution, wbich determine to a large extent the social-economic institutions of the society and state in question, as well as the constrains imposed upon these political relations by the economic structures which underpin them.

Hispania, LVIII/3, núm. 200 (1998) 841-879 
Una aproximación útil a la cuestión del valor interpretativo de la noción de "modo tributario" consiste en comparar dos formaciones sociales y estatales opuestas con el fin de destacar algunas características básicas en relación con estructuras sociales y políticas y su evolución, y para determinar hasta qué punto pueden ser comprendidas dentro de los términos de las relaciones de producción tributarias. En este artículo me basaré en el mundo romano tardío y el bizantino hasta el siglo XI, y en las formaciones estatales islámicas centrales en el mismo período (centrándome en particular en Siria, Iraq e Irán) y ver si realmente se pueden aislar tales elementos comunes; y si es así, hasta qué punto producen órdenes socio-políticos diferentes. Intentaré también indicar por qué surgieron estas diferencias. Inevitablemente, estas operaciones conllevan cierta generalización, pero espero que al menos seré capaz de indicar la importancia analítica de este modo de operar.

Mi discusión constará de una serie de cuestiones clave. Para empezar, ¿se puede emplear de forma útil el término "Estado» para cualquier sistema político?. En segundo lugar, ¿cuáles eran los mecanismos básicos de producción, extracción y redistribución del excedente? Tercero, ¿cuál era la naturaleza y constitución de la(s) élite(s) política(s) de estas formaciones, su articulación interna, y cuáles sus relaciones con las estructuras de poder político, con las fuentes de riqueza, agrarias o comerciales, y con su contexto cultural internacional?. Aunque en esta contribución aluda a ello de pasada, existe un cuarto factor que hace referencia al carácter del sistema religioso-ideológico de cada caso. ¿Qué efecto diferenciador tuvo éste, si alguno, -en términos de organización política, de poder, de motivación ideológica y en resultados prácticos, etc.--, en diferentes niveles sociales, en diversos contextos culturales, y a través de distintas regiones, dentro de los territorios de cada sistema estatal?; o, en otras palabras, ¿cómo intervinieron la religión y las creencias a la hora de definir y estructurar las formas de organización políticas, sociales y culturales, y los modos de tepresentación?

\section{LOS ESTADOS}

En relación con la primera cuestión, la respuesta obviamente depende de la manera en que definamos el «Estado». Estas definiciones han sido abundantes no sólo en la literatura que se ocupa de la organización política islámica primitiva, sino en aquella que trata de la formación estatal en general. No deseo aquí detenerme en este tema, pues ya se ha escrito bastante sobre esta cuestión, así que en este caso optaré por una definición puramente pragmática: un Estado existe allí donde se reconoce un región demarcada territorialmente (aunque esto no implica que se excluya la posibilidad de que sus tierras estén dispersas o separadas geográficamente), controlado por una clase dirigente centralizada de algún tipo, al menos en teoria, que habrá tenido y seguirá teniendo el mo- 
nopolio sobre el uso de la coerción, y que tiene el poder para imponer su autoridad sobre estos territorios por tales medios cuando sea necesario. Los medios a través de los cuales las diferentes autoridades centrales logran estos fines en diversos contextos históricos varía enormemente. En la mayoria de los estados premodernos hay siempre grandes diferencias en el grado y en la eficacia de la autoridad estatal como es el caso de las regiones montañosas o fronterizas, de difícil acceso y en las que no llega la supervisión estatal, o de los grupos «tribales» que nominalmente deben lealtad y que ocupan un territorio reivindicado por el estado, pero que no siempre se han sometido a la autoridad y al control estatal con facilidad.

Un estado está también representado por una ideología política particular o una serie de corrientes ideológicas que sirven para legitimar su existencia y su configuración política. Al mismo tiempo, las ideologias políticas actúan, al menos en parte, junto con muchas otras corrientes, para dotar a la población en general, o a partes substanciales de ella, con una identidad como sujetos, ciudadanos, quizás también como adeptos a un credo religioso o a un sistema de valores común, etc. Por supuesto que no todo esto necesariamente se interioriza para llegar a ser parte de la autopercepción de los estratos sociales o grupos en cuestión: en muchas ocasiones se mantienen impuestos desde el exterior, bien por comentaristas que describen la formación social en cuestión a partir de su propio punto de vista, a menudo muy extraño, o por comentaristas internos, generalmente pertenecientes a un sustrato socio-cultural diferente, que aplican categotías que a menudo tienen una alta carga simbólica.

Más importante aún, y a diferencia de las agrupaciones tribales o de clan, los estados construyen, o intentan construir, sistemas ideológicos y legitimadores más complejos de la mano de formas de extracción del excedente más impersonalizadas o institucionalizadas. Los Estados abandonan una administración basada en relaciones de parentesco o de linaje y en la explotación de formas de subordinación fundadas en el parentesco, en favor del establecimiento de un cuerpo de administración permanente y auto-regenerador, reclutado entre los grupos específicos de dentro del Estado (grupos tribales, por ejemplo), o de entre los de una determinada procedencia cultural o social, aunque el grado de desarrollo de este proceso varía. Los estados desarrollan, por tanto, estructuras institucionales (sistemas fiscales, organizaciones militares, etc.) que establecen sus propias series de roles y discursos al margen de las prácticas diarias de la sociedad «ordinaria». El Estado se convierte en un conjunto de instituciones especializadas y dominantes que pueden incluso emprender la creación ab initio de su propio personal administrativo, y que sólo pueden sobrevivir a través del mantenimiento del control sobre la apropiación y distribución de la riqueza excedentaria 1.

1 Ver MANN, M., «The Autonomous Power of the State: its Origins, Mechanism and Results", en HALL, J.A. (ed.), States in History, Oxford, 1986, págs. 109-136; los trabajos en CLAESSEN, H.J.M., y SkALNIK, P. (eds.), The Earby State, The Hague, 1978; y especialmente COHEN, R., «State Origins: a Reappraisalb, Ibid, págs. 31-75.

Hispania, LVIII/3, núm. 200 (1998) 841-879 
Esto es especialmente importante en relación con el potencial de las formaciones estatales para reproducirse, a diferencia del potencial de una dinastía o familia reinante, cuyo poder para mantenerse en el poder más allá de una generación está basado en la lealtad personal, la obligación y la reciprocidad. La evolución de una élite burocrática, que tiene conciencia de su función dentro del eje Estado/sociedad, identificada con un determinado conjunto de narrativas ideológicas y simbólicas, y que recluta y forma a su propio personal según el modelo de comportamiento y el papel institucional necesario para el mantenimiento, e incluso la expansión de estas estructuras, es un factor fundamental. Por supuesto, algunos Estados no se ajustan del todo a este modelo debido a que los problemas de identidad tanto regional como de linaje entorpecen los intentos de la autoridad central, incluso cuando ésta está apoyada por elementos de una burocracia civil y religiosa permanente, para mantenerse en el poder por más de una generación. Algunas formaciones políticas islámicas primitivas, tal vez de forma más notable el Califato Omeya, ejemplifican esta situación. En él, los conflictos de intereses entre el centro, el apoyo militar tribal fragmentado como consecuencia de rivalidades ideológicas heredadas, los subordinados convertidos al Islam, y los restos de las élites burocráticas tradicionales en las poblaciones urbanas conquistadas, todo ello matizado por un faccionalismo jdeológico y religioso muy asentado, se combinaban hasta producir una situación en la que la familia árabe gobernante y su clan de apoyo eran incapaces de movilizar recursos que neutralizasen ataques serios e ideológicamente bien fundados. Por el contrario, el imperio Sasánida que dominó Persia del siglo III al VII d.C., en el que el elemento iraní mostró una poderosa influencia en el desarrollo de las estructuras culturales y políticas islámicas, proporciona un buen ejemplo de una dinastía de destacable éxito. Pues el verdadero poder de la familia real dependía principalmente de dos factores clave. En primer lugar, jugó un papel principal el compromiso ideológico de un grupo poderoso de jefes dinásticos o de clanes regionales (la «aristocracia» Sasánida, de la que surgió la propia casa real) con la legitimidad de la dinastía dominante (la cual reivindicaba una cierta autoridad político-religiosa sancionada tanto por una reclamación de antigüedad en el linaje cuanto por el liderazgo militar). En segundo lugar (como ocurría en todas las formaciones estatales), los jefes apoyaron las reclamaciones del poder legítimo y acataron la autoridad de esa dinastía en tanto en cuanto los resultados del gobierno Sasánida no estuvieran en contradicción con sus propios intereses, ya fuesen ideológicos, políticos o económicos (en general los tres) ${ }^{2}$.

2 Para una reciente interpretación, ver Schippmann, K, Grunzjige der Gescbichte des Saanischen Reiches, Darmstadt, 1990; para unas más antiguas, ver CHRISTENSEN, A., LTran sous les Sassanides, Copenhague, 1944, y las secciones relevantes de FrYE, RN., The History of the Ancient Iran, Munich, 1984; idem, en The Cambridge History of of Iran, 3/1, Cambridge, 1983, págs. 153 y sigs.; y RuBIN, Z., «The Reforms of Khusro Anushirwan', en CAMERON, A. y CONRAD, L.A. (eds.), States, Resources and Armies: Papers of the Third Worksbop on Late Antiguity and Earby Islam, Princeton, 1994.

Higpanta, LVIJJ/3, núm. 200 (1998) 841-879 
El éxito o fracaso de los Estados para sobrevivir en un periodo de tiempo más o menos largo depende en última instancia de la relación entre otros cen. tros reales o potenciales de poder social (espacial o socialmente hablando) y los gobernantes y su élite dependiente por el control sobre la apropiación y distribución de los recursos (ya sean económicos o ideológicos; es importante destacar que el poder ideológico es funcionalmente igual de importante aquî). En algunos casos, una autoridad central puede sobrevivir durante un largo período de tiempo simplemente a través de la manipulación de elementos ideológicos y simbólicos claves en el sistema cultural de una formación social en su totalidad. Pero la autoridad política, esté legitimada de la forma que sea, siempre depende del control sobre la apropiación y distribución de la riqueza excedentaria, en los procesos concretos que sea. $Y$ estos procesos varían enormemente: impuestos estatales y rentas, redistribución ritual del producto desde las tierras del templo a los centros regios, servicios en los ejércitos reales y el mantenimiento a través de obligaciones para con un centro regio itinerante, todos ellos representan formas muy diferentes del mismo fenómeno esencial, cada uno depende de su propia manera de legitimación ideológica y simbólica, cada uno supone un desplazamiento de riqueza, en una serie variada de formas, desde los productores a través de diferentes medios a la autoridad política que puede utilizarla, en tanto en cuanto las condiciones lo permitan, para mantener y reproducir su propia posición, ya sea a través de coerción o de convicción. En algunas sociedades, los gobernantes invirtieron activamente en una mejora de las fuerzas productivas (a través de la construcción de canales, por trabajos de irrigación, etc.) para mejorar cualitativamente sus propias fuentes de ingresos. En otras fueron capaces, para este fin, de capitalizar la infraestructura laboral, y más importante, la ideológica, la 'economía moral' de las comunidades campesinas.

Los estados pueden ser identificados en otros dos niveles, igualmente importantes. Ellos tienen una existencia ideológica que no tiene que estar necesariamente atada a su verdadera eficacia o poder político e institucional. Las ideologías políticas y otros sistemas de creencias pueden adaptarse y sobrevivir en condiciones que han evolucionado mucho de aquéllas a partir de las cuales originariamente surgieron, siempre y cuando las contradicciones entre ambas no sean extremas. Los estados que responden a las necesidades funcionales a largo plazo de la sociedad humana proporcionan los mejores ejemplos, y en particular incluyen los sistemas religiosos (el Islam o el Cristianismo, por ejemplo), que pueden bajo determinadas circunstancias liberarse de la condiciones tanto políticas como sociales y económicas que los originaron. Del mismo modo, las ideologías políticas pueden ser extremadamente flexibles, y están en cualquier caso normalmente inextricablemente unidas a sistemas religiosos. Éstas pueden proporcionar una lógica al conflicto cuando no existen razones obvias o visibles para la lucha por los recursos materiales, por ejemplo. Y además pueden ser extremadamente poderosas. Por tanto, muchos estados fueron, de hecho, poco más que territorios gobernados por un rey que sólo lo era nominalmente, en los que el poder real lo ejercía una clase de magnates 
cuya posición en un principio bien podía haber dependido del gobierno central y/o de las condiciones en las cuales se formó el Estado (por conquista, por ejemplo) pero los cuales, merced a su verdadero control de los recursos, y a otras condiciones históricas, eran de hecho independientes. Pero la idea de un reino o estado centralizado, junto con el poder residual de los conceptos asociados a ella, era suficiente para mantener al menos una ficticia unidad de identidad. Uno de los resultados era que desde fuera estas formaciones podian seguir siendo vistas como estados unitarios.

A la hora de pensar en el «poder estatabs y en su eficacia, es importante destacar que cada formación cultural encarna toda una gama de subconjuntos ideológicos y simbólicos, si bien representados en intereses socio-económicos, aunque estén engarzados en el lenguaje del universo simbólico dominante; éstos, a su vez, juegan un papel fundamental en la formas en las que un particular conjunto de relaciones de poder se crea, funciona, y se regenera o desaparece. En ocasiones, narrativas alternativas pueden ser interpretadas a partir de esta gama de posibilidades, dando cuenta de las realidades percibidas por distintos grupos dentro de la cultura en cuestión ${ }^{3}$. Pues el poder efectivo de los gobernantes estaba fuertemente influido y modulado por la naturaleza de las comunicaciones, de las identidades y tradiciones regionales, por las dificultades inherentes a la administración y la recaudación de impuestos sobre los productores, y por la lentitud de las respuestas represivas contra la oposición. Una de las cuestiones más importantes que debe plantearse este trabajo es, por tanto, cómo los estados bizantinos e islámicos primitivos resolvieron el problema de la extracción del excedente a los productores, a la vez que se aseguraban la cantidad de excedente adecuado para su propio mantenimiento y reproducción. Sobre la base de las consideraciones planteadas al principio, no dudo en emplear el término «Estado» para describir el marco básico de las relaciones políticas de poder tanto en el contexto tardorromano y bizantino como en el del Oriente Medio islámico en el período en cuestión. Sin embargo, tal y como vamos a ver, en cada caso se representan estadios muy diferentes de la formación estatal, y con modos muy diversos de organización institucional.

Esto nos lleva, por consiguiente, a la segunda importante consideración que se subrayó en la introducción. Pues, tal y como veremos, en los dos casos la respuesta de élite estatal/aristocracia fue administrar directamente este doble proceso (a través de la asignación de ingresos, feudos a otras formas de asignación y distribución). Tal y como ya he sugerido, el determinante secundario, y la constricción principal a la autonomía del estado tributario era la contradicción in-

3 He intentado demostrar las maneras en las que estos elementos entrelazados pueden separarse para mostrar la relación causal en juego durante un periodo de transformación social e ideológica, ver HALDON, J., «deology and Social Change in the Seventh-Century: Military Discontent as a Barometen, Kio, 68, 1986, págs. 139-190 (rempreso en idem, State, army and society in Byzantium, Aldershot, 1996, II), en el que el papel de los soldados y de sus origenes sociales es analizado en relación a su intervención en el nivel de la politica estatal y la ideología imperial.

Hitpania, LVIII/3, núm. 200 (1998) 841-879 
herente entre los intereses del «Estado» (el gobierno, la élite burocrática, la facción aristocrática dominante en la corte o cualquiera de las formas en las que el centro expresaba su posición con respecto a las provincias o las áreas extetiotes a su control físico inmediato) y otras partes de la clase gobernante en relación al control, primero sobre la apropiación del excedente, y segundo sobre su distribución.

\section{IMPUESTO, TRIBUTO Y RENTA: MODALDADES DE EXTRACCIÓN DEI EXCEDENTE EN EL IMPERIO ROMANO ORIENTAL}

La extracción del excedente era fundamental para la supervivencia de ambos sistemas políticos, y en los dos casos el motivo primordial era el reclutamiento y manutención de las fuerzas militares para asegurar su apoyo, sus exigencias territoriales y el mantenimiento del orden político. En el Estado tomano oriental, aunque los procedimientos técnicos variaron y evolucionaron en el tiempo desde el Imperio Romano tardío hasta los siglos XI y XII, la tierra se valoraba en función de si estaba ocupada y cultivada, de la naturaleza y (en algunos periodos) del valor medio de su producción en el mercado (dentro de una región determinada), y de su calidad (que dependía de la zona y/o de la cosecha). Para el ganado se aplicaba un método similar de contabilidad de la explotación pastoril o granjera. Los cultivos especializados — vid, aceitunas, por ejemplo- - tributaban en función de la calidad y la tasa de producción. El sistema de apropiación del excedente se mantenía y se desarrollaba a través de una burocracia fiscal asalariada, que mantuvo los registros de la tierra centrales y regionales, los cuales fueron a su vez, desde el siglo VII y con seguridad desde el IX, actualizados de forma regular.

El excedente era recaudado y redistribuido a través de diversas formas. Los terratenientes privados generalmente recaudaban las rentas en metálico o en especie, de acuerdo con la naturaleza del contrato o del arrendamiento y en relación con las condiciones económicas del período o de la zona, o de ambas (la disponibilidad de mercados era esencial), El estado extraía excedentes tanto en metálico como en especie (para impuestos regulares sobre la tierra, por ejemplo), así conu a través de diversas formas de servicios en trabajo: el mantenimiento de estaciones de correos y de caballos, por ejemplo, o la producción de hierro, de tejidos, etc., que se calculaban a través de unas tablas de equivalencia determinadas de forma centralizada. Del mismo modo, a veces se exigía a las comunidades locales que ayudasen en la construcción de caminos y puentes o de fortificaciones, $y$ que alojasen y alimentasen a los soldados y sus oficiales, a los oficiales imperiales y mensajeros, etc. A la altura del siglo IX, y posiblemente ya desde el VII, el estado reclamó la producción de armas y de variados artículos de equipamiento militar a artesanos adecuados entre la población provincial, exigidos como corveas adicionales; se hicieron comunes gravámenes extraordinarios sobre el alimento y el grano mientras que el propio servicio militar, al no haber exención a los impuestos principales de tierra y capitación, liberó a las poblaciones de gravámenes extraordinarios e imposicio- 
nes similares ${ }^{4}$. Pero el rasgo principal de todas estas formas de apropiación del excedente es que fueron, sin excepción, obtenidas a través de la coerción extraeconómica, bien a través de las obligaciones «por costumbre» y del poder de la ley, que en muchos casos se apoyaban en último término en el poderío militar imperial, bien a través de la simple amenaza o intimidación por parte de los oficiales del estado, de la Iglesia o de los terratenientes privados. Esta era una sociedad agraria de campesinos y artesanos rurales, y ellos eran la única fuente real de producción de riqueza.

La pérdida de control sobre gran parte de los Balcanes, y la conquista por los árabes de las provincias orientales al sur de Asia Menor así como de la fértil región de Cilicia a principios del siglo VIII marcó, tal y como se reconoce habitualmente, un cambio substancial en las condiciones de existencia del Imperio. El gobierno fue compelido a reestructurar los métodos a partir de los cuales extraía los recursos, así como los medios de distribuirlos. Tuvo también que reducir los gastos para equipararlos a la mermada base de recursos a su disposición. Los efectos de las invasiones y guerras sobre la población en las zonas más afectadas y, por tanto, sobre la capacidad productiva, sobre las líneas de comunicación y sobre la capacidad del estado para mantener un sistema público de transportes, representaron todos ellos grandes cambios de las condiciones sobre las cuales se fundaba el Imperio Romano. Pero a ellos les siguió un conjunto de cambios concomitantes, se modificaron los procesos burocráticos que garantizaban la extracción de recursos así como el mantenimiento y apoyo de las unidades militares; también cambiaron las relaciones de poder entre el gobierno central y sus representantes a distintos niveles en las provincias.

\section{POLIITICA Y PODER ESTATAL CA. 600-1100}

A pesar de los problemas a los que se enfrentaba la mitad oriental del Imperio a mediados y finales del siglo V, su gran cohesión estructural y su flexibilidad le permitieron sobrevivir tanto a los ataques exteriores como a la desintegración de las pautas económicas y comerciales 5 . A finales del siglo $\mathrm{V}$ y principios del VI se llevó a cabo una importante reforma en la acuñación de monedas de bronce que iba a proporcionar el marco básico para el sistema monetario del Imperio hasta el siglo XII ${ }^{6}$. Durante el VI el Imperio fue lo suficientemente fuerte como para recuperar grandes territorios que habían sido

4 Sobre las varias formas de impuestos y de corveas reales en el Estada bizantino, ver OIKONOMIDEs, N., Fiscalité et exemption fiscales à Byzance (IX-XI s.), A tenas, 1996.

5 Acerca de los acontecimientos políticos, ver JoNes, A.H.M., The Later Roman Empire, 284-602, Oxford, 1964, págs. 217-237; SiEIN, E., Histoire du Bas-Empire, I, París-Brujas/Amsterdam, 1959, págs. 351-364; II, París-Brujas/Amsterdam, 1949, pag. 7 y sis., $177 \mathrm{y}$ sis.

6 Acerca de estos desarrollos, ver HI:NDY, M.F., Studies in Byzantine monetary economy, Cambridge, 1985, paig. 475 y sigs.; Jonfs, Later Roman empire, pág. 207 y sigs., 235 y sigs. 
perdidos frente a invasores o colonos. Aunque el coste de este expansionismo fue muy importante, el Estado romano del este, a principios de la década de los 30 del siglo VII, todavía abarcaba el norte de África, Egipto, la Siria moderna, Iraq y Jordania occidental, junto con el Líbano y Palestina, Anatolia, gran parte de los Balcanes, Sicilia, Cerdeña y partes considerables de Italia, aunque reducidas por los Lombardos. La mayor parte de los Balcanes estaba fuera del control central efectivo, bajo el dominio de los eslavos y por otros invasores. Pero en la década de los 30 los árabes emergieron de la Península de Arabia bajo la bandera del Islam y de la guerra santa, y la resistencia imperial no fue más que simbólica. En el 642 se había perdido todo Egipto y las provincias de Oriente Medio, las fuerzas de Arabia habían penetrado profundamente en Asia Menor y en Libia, y las fuerzas imperiales se habían retirado hacia la Península de Anatolia, donde se asentaton a lo largo de las provincias de la región como único medio de mantenerse. Por lo tanto, en un periodo de unos doce años, el Imperio perdió prácticamente la mitad de su territorio y tres cuartas partes de sus recursos, una drástica pérdida para un estado imperial que todavía tenía que mantener y equipar un ejército considerable y una burocracia administrativa eficaz si es que quería sobrevivir ${ }^{7}$. Aunque muchos de los acontecimientos que condujeron a esta transformación estaban en marcha mucho antes de la crisis del siglo VII, fue esta coyuntura la que sirvió de detonante y promovió las respuestas estructurales subsiguientes.

Las derrotas y la reducción territorial que resultó de la expansión del Islam en el Este a partir de la década de los 40 del siglo VII, por un lado, y la liegada de los búlgaros y el establecimiento de un Janato búlgaro en los Balcanes a partir de la década de los 80 , por otro, alteró radicalmente las condiciones políticas de la existencia del Estado romano oriental. La transformación de las estructuras administrativas estatales resultante dio lugar a un ejército que estaba basado casi enteramente en principios defensivos, en los que la guerra ofensiva se convirtió en algo inusual hasta mediados del siglo VIII, y al que el gobierno imperial animó a que evitase en la medida de lo posible batallas planeadas o confrontaciones abiertas con las fuerzas enemigas.

Los ejércitos de tierra del Imperio tardorromano se transformaron en la práctica en milicias provinciales, aunque parece ser que siempre un comandante militar de cada región mantuvo un ejército permanente de soldados "profesionales». Las regiones a lo largo de las cuales se establecieron estas fuerzas, y que finalmente, en el proceso de transformación de las antiguas estructuras administrativas provinciales, evolucionaron hasta convertirse en unidades administrativas, se denominaron themata, un término que originariamente significaba simplemente una región asignada a un ejército. Se desarrolló una estrategia de guerra de guerrillas que permitió a las fuerzas enemigas penetrar en

7 Una breve historia político-militar de este periodo, en Osrrocorsky, G., History of the Byzantine State, Oxford, 1969, págs. 83-95, 100-117; y WHIrTow, r., The Making of the Orthodox Byzantium, Londres, 1996, págs. 38-133. Acerca de la proporción de los ingresos perdidos, ver Hendy, Monetary Economy, pág. 620.

Iiipania, LVIII/3, núrn. 200 (1998) $841-879$ 
los territorios fronterizos y una vez allí acabar con sus bases y molestarlas y acosarlas hasta que desintegrarlas o forzarlas a retornar a sus tierras. Los oficiales bizantinos desplegaron en muchas regiones una estrategia de «tierra quemada", y se animó a la población de las regiones en peligro a que mantuviesen puestos de vigilancia para así poder reurir el ganado y otras bienes muebles y refugiarse en fortalezas montañosas, privando así al enemigo de la posibilidad de realizar incursiones y capturar el botín. A pesar de que algunos emperadores emprendieron a título individual expediciones ofensivas en el período ca. 660730 , éstas estaban generalmente diseñadas como una forma de prevenir un gran ataque del enemigo sobre el territorio del Imperio romano en Asia Menor, o tenían un carácter punitivo, se trataba más bien de ataques de venganza por motivos ideológicos contra importantes objetivos enemigos y sin valor estratégico duradero pero con implicaciones para la moral militar. Aunque se registraron algunos éxitos notables, muchos de estos ataques fracasaron y dieton lugar a importantes derrotas y pérdidas de hombres y de material.

Sólo a partir de la década de los 30 del siglo VIII la situación empieza a cambiar. La estabilidad política interna, los comienzos de la recuperación económica a finales de este siglo, y las disensiones entre los enemigos, permitieron que los bizantinos restableciesen un cierto equilibrio a la altura del año 800. A pesar de ocasionales reveses, y de una situación política internacional a menudo desfavorable, los bizantinos fueron capaces de iniciar una política más ofensiva en relación al poder islámico en el este, y al de los búlgaros en el norte, en este último caso combinando diplomacia y actividad misionera con amenazas militares. Desde principios del siglo IX se restableció la autoridad imperial sobre gran parte del sur de los Balcanes y de las regiones costeras de Iliria; al mismo tiempo, sucesivas victorias en el centro de Asia Menor a partir de la década de los 60 del siglo XI (pese a algunos reveses, tales como el saqueo árabe en 842 de la importante ciudad-fortaleza de Amorion) establecieron una nueva frontera y pusieron al Califato a la defensiva. Hacia principios del siglo $\mathrm{X}$, al estar el Califato debilitado debido a sus conflictos internos, los bizantinos estaban empezando a tener cierta ventaja y, a pesar de la feroz y a menudo eficaz resistencia de los caudillos locales musulmanes (como por ejemplo los emires de Alepo en la década de los 40 y de los 50 del siglo X), lograron una serie de brillantes reconquistas de enormes franjas territoriales en el norte de Siria y de Iraq, la aniquilación del segundo Imperio búlgaro, y el comienzo de la reconquista de Sicilia y del sur de Italia. Durante los últimos años del siglo IX y las dos primeras décadas del X, el recientemente cristianizado Estado Búlgaro representó una seria amenaza para el Imperio - Constantinopla fue brevemente sitiada-, pero las relaciones pacíficas, seguidas por una creciente influencia bizantina sobre la cultura y la sociedad búlgaras, perduraron durante la mayor parte del siglo X. La renaciente hostilidad búlgara dió como resultado una serie de largas y costosas guerras, que culminaron en la destrucción final de un reino zarista búlgaro independiente después de 1014 y su absorción en el Imperio. En la época de la muerte del emperador-soldado Basilio II, «el matador de búlgaros», en 1025, el Imperio era otra vez el principal poder político y

Hitpania, J.VIII/3, nüm. 200 (1998) 841-879 
militar de la cuenca mediterránea oriental y del sudeste de Europa, rivalizando sólo con el califato Fatimí de Egipto y Siria ${ }^{\text {. }}$.

Pero la guerra ofensiva que se desarrolló a partir de la mitad del siglo IX tuvo efectos, a su vez, sobre la administración y la organización de las estructuras administrativas fiscales y militares estatales. Las milicias provinciales dejaron de ser poco a poco adecuadas para las necesidades de esta campaña, al haber ido quedando atadas a sus localidades, a lo que era en realidad un tipo de estrategia de guerrilla, $y$ a las campañas estacionales organizadas por asaltantes átabes o búlgaros. En su lugar, se empezaron a desarrollar ejércitos de tierra regulares con una estructura táctica más compleja, con técnicas de lucha y armas especializadas, y con un élan más ofensivo, auspiciados en parte por una nueva élite social de comandantes militares que eran también grandes terratenientes, y por otra, alentados y financiados por el Estado. Las tropas mercenarias jugaron un papel cada vez más destacado cuando el Estado empezó a conmutar el servicio militar de los ejétcitos provinciales por dinero con el que poder contratar a profesionales: a mediados del siglo XI, una gran proporción de los ejércitos imperiales estaba formado por unidades mercenarias reclutadas entre las poblaciones indigenas junto con mercenarios normandos, rusos, turcos y francos, principalmente de caballería, pero incluyendo también tropas de infantería (como por ejemplo, la famosa guardia Varega) ${ }^{\text {? }}$.

El expansionismo del período ca. 940-1030 tuvo, sin embargo, consecuencias negativas. Las crecientes demandas estatales chocaron con una mayor oposición de la aristocracia a pagar impuestos: el faccionalismo político en la corte, que reflejaba a su vez el desarrollo de nuevas tensiones sociales dentro de toda la sociedad y en un contexto caracterizado por un gobierno imperial débil y oportunista, dio lugar a fracasos políticos, a una sobrevaloración de la fuerza militar imperial, y al rechazo de estructuras de defensa. Cuando los grupos de bandidos turcos Sel fueron capaces de hacer pedazos a una importante fuerza imperial en 1071 y lograron capturar al emperador Romano IV (abriendo a futuros enfrentamientos entre facciones en Constantinopla), el Imperio no fue capaz de organizar el contraataque, dando lugar a una lenta ocupación del centro de Asia Menor por parte de pastores nómadas y sus rebaños, tierras que el Imperio acabó perdiendo ${ }^{10}$.

El resultado de la llegada de los Selŷuquíes y la derrota de las fuerzas bizantinas en 1071 privó a estos últimos de la parte central y oriental de Anatolia,

8 WHITTow en Making of the Onthodox Byzantium presenta un estudio útil y breve de la historia de este periodo.

9 Sobre las reconquistas, ver WHITTOW, The Making of the Orthodox Byzantium, págs. $310 \mathrm{y}$ sigs.; y acerca del desarrollo organizativo administrativo y militar, ver OIKONOMIDES, N. 'L'Évolution de l'organisation administrative de l'empire byzantin au $\mathrm{XI}^{\circ}$ siècle', Travaux et Mémoires, 6, Paris, 1976, págs. 125-152.

10 Ver Cheynet, J.C., Pouvoir et contestations à Byzance (963-1270), Paris, 1990; y para la historia general del periodo ver los capitulos relevantes en ANGOLD, M., The Byzantine Empire 1025. 1204: a Political History, Londres, 1984. 
quedando así limitados a las regiones costeras, aunque en el oeste, más abierto a posibles ataques e infiltraciones desde la meseta, incluso esta posición siguió siendo precaria. Bajo el mandato de los emperadores de la dinastía de los Comneno (1081-1185), y en parte debido a una eficaz explotación particularmente de la primera y de la segunda Cruzada, se restableció la autoridad bizantina a lo largo de la parte occidental de la península. Sin embargo, tras las desastrosas batallas posteriores contra los Selyuquúes en Myriokephalon en 1176, se perdió el control efectivo sobre gran parte del territorio reconquistado.

\section{ESTADO Y SOCIEDAD}

Parece claro que el Estado jugó un papel principal en la economía bizantina ", al estar limitado por y en cierta medida al definir la naturaleza de las relaciones económicas claves, en particular aquéllas que determinan la naturaleza de la apropiación, distribución y consumo del excedente. Esto es especialmente claro en relación a la emisión y circulación de la moneda que, incluso si tenemos en cuenta las considerables fluctuaciones de la pureza del nomisma de oro y de sus fracciones, y la distribución y calidad de las monedas de bronce de cuenta, continuó siendo el principal mecanismo a través del cual el Estado convertía la riqueza social en recursos fiscales transferibles ${ }^{12}$. La emisión de moneda estaba dirigida principalmente al mantenimiento de la maquinaria estatal, de modo que ésta se apropiaba y consumía la riqueza a través de algo que podría ser descrito como un mecanismo de redistribución fiscal. El Estado emitía oro que iba a parar a las manos de su burocracia y de sus ejércitos, en forma de salatios y de obsequios, los cuales intercambiaban una porción substancial de éstos por los artículos y servicios necesarios para su mantenimiento. De este modo el Estado podía recaudar gran parte de la moneda que había puesto en circulación a través de los impuestos, sobre todo al llevar una política fiscal que exigia el pago de los impuestos en oro y ofrecía el cambio en bronce. Hubo momentos en los que el sistema estaba limitado por las circunstancias: en particular, el siglo VII parece haber sido un período en el que las demandas sobrepasaron los recursos en efectivo dando lugar, por ejemplo, a acuerdos ad boc para abastecer de soldados en las provincias, en especie y para recaudar impuestos en forma de corveas estatales u otras imposiciones extraordinatias ${ }^{13}$.

11 Este es un argumento a menudo destacado, por ejemplo, por HENDY, Studies in the Byzantine Monetary Economy, pág. 602 y sigs., 662 y sigs.; y también en (Economy and State in Late Rome and early Byzantium: an Introductions, en The Economy, Fiscal Administration and Coinage of Byzantium, Londres, 1989, I, pás. 1-23. Ver también HALDON, "Some Consideration on Byzantine Society and Economy in the Seventh Centurys, Byzantiniache Forschungen, 10, 1985, págs. $75-112$, esp. 80 y sigs.

12 Transferible, porque una parte substancial de la riqueza extraída por el Estado era siempre en forma de materias primas, servicios al'Estado de una clase u otra, trabajo, etc.

13 Ver HAIDON, J.F., «Synonê Reconsidering a Problematic Term of Middle Byzantine Fiscal Administration", Byrantine and Modern Greek Studies, 18, 1994, pág. 116-153.

Hispania, LVIII/3, núrn. 200 (1998) 841-879 
Se ha admitido que la consecuencia final de este monopolio estatal de la distribución y circulación de la moneda, y el peso del aparato fiscal sobre la población activa, fue un factor importante, aunque no sea probablemente el más importante, a la hora de impedir la inversión en intercambios comerciales no relacionados con el proceso fiscal; y en una sociedad en la que todas las formas de estatus y de ascenso estaban ligadas al Estado (incluida la propia identidad de la aristocracia), esto representaba un considerable obstáculo para la expansión de una parte de la economía que no se relacionaba directamente con la actividades estatales. Es cierto que esta situación fluctúa: el aumento de la inversión agrícola y de la población, y, en consecuencia, de la base impositiva del Estado durante los siglos X, XI y XII, parece haber venido acompañada por un incremento correspondiente del intercambio a escala local y de una pequeña producción independiente de mercancías. Pero incluso las demandas del aparato estatal y el hecho de que la élite social permaneciese estrechamente vinculada a éste, sirvieron de obstáculo para el desarrollo de relaciones de mercado totalmente libres de la intervención estatal. Los efectos de la supervivencia del centralismo estatal de la antigüedad son claramente reconocibles ${ }^{14}$.

La posición central del Estado se hace especialmente evidente en la historia de los intentos por conservar el control de sus recursos fiscales. Es sintomática la tensión entre la autoridad central y la élite terrateniente, al influir ambas en la manera en la que el Estado calcula, incrementa y distribuye los impuestos. La capacidad del Estado en los siglos VII y VIII para desarrollar un control total sobre su base impositiva determinó de modo directo la evolución de la aristocracia bizantina en sus épocas media y tardía. De manera similar, las guerras civiles y las crisis fiscales del gobierno central especialmente a finales del siglo $\mathrm{X}$ y en el XI, y los correspondientes cambios en el modo de reclutar y mantener al personal del ejército, así como las modificaciones dentro de la administración provincial y de la central, civil y fiscal, pueden relacionarse con la naturaleza de la relación entre el Estado y su base fiscal ${ }^{15}$.

No hay ninguna duda de que las demandas del Estado y su relación con la población activa y con las élites sociales que él mismo mantenía e incluso reproducía, eran rasgos determinantes para el funcionamiento de la economía. El sistema fiscal era enormemente complejo, la ideología política imperial

14 Para una visión general de las diferentes funciones de la acunación de las monedas de oro $y$ bronce $y$ su posición con respecto a las cuestiones fiscales estatales, ver HALDON, J.F., "Some Considerations on Byzantine Society and Economy in the Seventh Century', esp. págs. 80-84, y Hendy, M. F., (Byzantium, 1081-1204: the Economy Revisited》, en The Economy, Fiscal Administration and Coinage of Byzantium, III.

15 Ver mis comentanos en "The Army and the Economy:the Allocation and Redistribution of Surplus Wealth», Mediterranean History Revien, 7/2, 1992, págs. 133-153. Es particularmente problemático el hecho de que el gobierno central estuviese frecuentemente representado en las provincias por los pincipales oficiales que, a su vez, eran miembtos de la élite social, perjudicando asi considerablemente los intereses del centro en particular a la hora de poner en marcha la política fiscal.

Hispania, LVHI/3, núm 200 (1998) 841-879 
dominaba el universo simbólico de todos los bizantinos, los representantes del aparato civil y del militar eran ubicuos. De este modo, las transformaciones sociales y los conflictos ocurridos por y en el Estado, eran posibles debido a la existencia del Estado mismo. Es fácil exagerar la importancia de estas relaciones, y debemos recordar que en una sociedad preindustrial había miles de lugares en los que el control estatal en el 'nivel microestructural' de la vida social tenía, obviamente, poco efecto. Pero la existencia de un Estado Romano Oriental afectaba profundamente a la estructura económica y social del Imperio oriental.

\section{LA FORMACIÓN DE LOS PRIMEROS ESTADOS ISLÁMICOS: ÉLITES DE PODER Y PARENTESCO}

Las primeras conquistas islámicas, la extinción del estado persa Sasánida, y la pérdida del Imperio Romano Oriental de los territorios de Oriente Medio y del norte de África, marcó un cambio profundo en la evolución histórica de las regiones afectadas así como en las circundantes. Más importante aún para nuestra perspectiva, nos brinda la oportunidad de poder estudiar la creación ab initio de un nuevo Estado y de una formación política que se derivan en parte de las que les preceden, e inspiradas en parte en unos imperativos ideológicos radicalmente novedosos y en sus implicaciones sociales y económicas. Que podamos o no confiar en los registros históricos islámicos, y que la expansión inicial fuera resultado o no de una estrategia coordinada, el hecho es que hacia la década de los 70 del siglo VII se estableció una importante formación política nueva, apoyada por una élite dirigente que basó su legitimidad en una combinación de éxito en la conquista y parentesco, y en el mantenimiento de una ejército sostenido a través de una mezcla de salarios y subvenciones estatales y de empresas privadas ${ }^{16}$.

La cuestión de la distribución de recursos y de ingresos, y el grado de acceso de los califas a estos últimos en una zona dada fue, desde el principio, un problema fundamental en la nueva política. No hay duda de que en la década de 670 , y sin duda en la del 690 , existía un sistema de impuestos y un aparato fiscal, un ejército y un sistema jurídico controlados de manera centralizada, administrados al menos en teoría desde Damasco; es decir, estaban presentes todos los elementos claves de un Estado. Aunque el grado de control sobre los recursos ejercido por los califas sigue estando poco claro, en el caso de Egipto,

16 Acerca del problema de la tradición de fuentes históricas (todos los documentos históricos datan de finales del siglo VIII en adelante), ver NoTH, A., con CoNran, L.A., The Earby Arabic bistorical tradition: a source-critical study, (trad. por) BONNER, M., (Studies in Late Antiquity and Early Islam 2), Princeton, 1994; DONNER, F.M. The early Islamic conquest, Princenton, 1981. Para la cuestión de la conquista y de si existía o no una estrategia central, ver DONNER, F.M., "Centralized authority and military autonomy in the early Islamic conquest", en CAMERON, A., Conrad, L.A.(eds), States, Resouces and Armies: Papers of the Third Worksbop on Late Antiquity and Early Islam, Princeton, 1995, págs. 337-360, que incluye discusiones y más bibliografia.

Hi.pania, LVIII/3, núm. 200 (1998) 841-879 
donde pervivía una cantidad considerable de prácticas fiscales detalladamente probadas, parece ser que la administración islámica emplazada en al-Fustāt era más o menos autónoma en relación con la financiación y la administración de su ejército y de su sistema fiscal.

Había dos instituciones que, junto con las prácticas y tradiciones que venían asociadas a ellas, eran esenciales para la administración fiscal y para la distribución de recursos en el Estado islámico temprano. La primera de ellas es el diwan, una institución que no tiene equivalente entre los estados cercanos. Establecida en origen por el califa Umar como respuesta a los resultados de la primera oleada de conquistas a finales de la década del 630, el principio sobre el que funcionaba el dinān era que los musulmanes no se asentarían sobre la tierra, sino que permanecerían como una casta hereditaria separada dependiente de la Umma, que es la comunidad islámica o, en la práctica, el Estado, estableciendo asentamientos o plazas fuertes y extrayendo sus rentas de los ingresos obtenidos en los territorios conquistados de alrededor. El término $d \bar{t}$ wän hace referencia a una lista de nombres, que iban acompañados de la cantidad de salario ('afa) que se le pagaba mensualmente a cada uno (las tasas variaban según criterios de antigüedad en la asociación con el Profeta, en su conversión al Islam y en la conquista). Las rentas para el mantenimiento del $d \bar{t}$ wän se imponían sobre los territorios en los que habitaban los soldados o las personas a su cargo, se recaudaban en la capital provincial, y tanto la recaudación como la distribución corrían a cargo del gobernador provincial, en teoría asignado por el Califa.

La segunda institución era la de fay'. Este término se refiere a los recursos en relación con la propiedad de la tierra y a otros bienes inmuebles adquiridos a través de la conquista. Como un resultado natural de la conquista, se extendió la creencia de que todo el botín sería dividido y repartido entre los conquistadores, de modo que los ingresos de estas tierras serían por lo tanto simplemente divididos, bajo supervisión provincial, y sin interferencia del Califa. Sin embargo, desde el principio los Califas intentaron obtener el control de parte de estos ingresos para sus propios propósitos administrativos, sin los cuales no podrían mantener un aparato de gobierno central, ni reclutar y aumentar a sus fuerzas militares. Esta tensión causó problemas desde el comienzo. El asesinato de 'Utmān se ha asociado con esta disputa originada en Kūfa.

Este problema de los tecursos y del funcionamiento de las instituciones del diwän y fay' constituye la cuestión singular más importante alrededor de la cual se centró la lucha política a principios del periodo islámico ${ }^{17}$. E n tiempos de Marwān I (683-4/64 H) el dīwān estaba en teoria cerrado, aunque en una serie

17 Ver especialmente Tritron, A.S., «Notes in the Muslim system of pensions", Bull.School of oriental and African Studies, 16, 1954, págs.170-172; SIMONSEN, J.B., Studies in the genesis and early development of the Caliphal taxation system. Copenhague, 1988; PuIN, G.R., Der Diwan won cUmar ibn al-jattab, Tesis Doctoral, Bonn, 1970 y Hinds, G.V., «The murder of the Caliph cUthmans, Int. Journal of Middle East Studies, 3, 1972, págs. 451-459 y reimpreso en Idem., Studies in Early Islamic History, (eds.) BaCliARACH,y., CONRAD, L., Crone, P., Princeton, 1995, págs. 29-55. 
de llamamientos de apoyo, varios contendientes por el poder del Califa incorporaron los nombres de sus seguidores a la lista. Esto funcionó en términos generales, así que parece claro que los ingresos derivados de la incorporación de uno mismo y de sus subordinados en el tivan eran considerados como algo importante. Las rentas destinadas al diwän eran recaudadas a nivel provincial, no desde Damasco, un indicativo más de la relativa autonomía fiscal de las provincias, incluso de las que estaban bastante próximas a las tierras principales del Estado. La localización en la recaudación y redistribución de los recursos entre el ejército parece algo evidente si se tiene en cuenta que a menudo se pagaban los salarios en especie, como parece haber sido el caso de Egipto a finales del siglo VII y, probablemente, el de Palestina en el mismo período ${ }^{18}$. Los esfuerzos de los oficiales administrativos del Califa por intervenir directamente en la recaudación y distribución de los recursos destinados a pagar a los militares eran vistos por el ejército local como un perjuicio. Los ejércitos se sustentaban por otros medios aparte del de los salarios de los que estaban incluidos en el diwāan. En algunos casos se pagaba directamente al ejército de una determinada provincia o región con los tributos recaudados entre los pueblos vasallos vecinos; en otros, en provincias en las que no había un ejército asentado pero en las que se podían obtener ingresos suficientes eran adscritos a un determinado ejército, como era el caso de algunas partes de Iraq. Los ejércitos de campaña eran a menudo reclutados sobre la base de una promesa de botín por las expectativas de éxito, mientras que los gobernadores provinciales o los califas podían reclutar fuerzas de forma temporal para campañas concretas, empleando para ello las reservas o los ingresos procedentes de otras fuentes. Pero de forma general, todas las evidencias históricas apuntan a que la paga - 'atạ- de los que estaban registrados en el dizwan de cada provincia se extraía de los ingresos de dicha provincia, sacados a su vez de los territorios conquistados y de otras fuentes - fay'- y que pertenencían a los que estaban inscritos en él por derecho de conquista, y no al Califato ni a cualquier otra institución central.

\section{LA POLfTICA DE REDISTRIBUCIÓN}

El excedente que quedaba tras haber pagado los salarios al ejército era el principal punto de discordia entre las provincias y el centro. Una proporción iba dirigida a Damasco, mientras que las pruebas muestran que en Egipto la cantidad era muy pequeña: se ha estimado en torno al 5\%. Dada la proximidad de estas dos regiones y la relativa facilidad con la que se podía mover el capital en esta distancia, parece justificada la afirmación de que las provincias más distantes enviaban la misma proporción o incluso una algo menor ${ }^{12}$. Los gobernadores individuales que adoptaban diversas actitudes con sus provincias y con

18 DONNER, F.M., "The formation of the Islamic State", Journal of the American Oriental Society, 106, 1985, pigs. 283-295.

19 DenneTT, D.C., Conversion and poll-tax in early Islam, Cambridge, Mass., 1960.

IIipanit, LVIli/3, núrn. 200 (1998) 841-879 
el Califa de turno indudablemente actuaban de manera diferente según el contexto, y algunas evidencias sugieren que determinados gobernadores fueron mucho más eficaces que otros a la hora de extraer el excedente para el Califa, o por el contrario, de mantenerlo para su uso en la provincia.

Las limitaciones en la extracción de ingresos de la provincias por parte de los Califas alentó el desarrollo de las tierras califales, constituídas a través de la conquista, de la confiscación o de la herencia familiar y de las que se podían obtener sustanciales rentas. Los Marwāníes poseían considerables tiertas en Arabia e Iraq, y probablemente también en Siria, y las rentas obtenidas de ellas eran empleadas tanto para mantener la corte como para pagar ejércitos mercenatios que fuesen fieles a los propios Califas y que no estuviesen sujetos a lealtades provinciales. El desarrollo de tales propiedades territoriales afectó a los modelos de explotación agraria y de asentamiento de la tierra, así que parece que la intervención 'estatal' tuvo un importante impacto en la economía de estas regiones ${ }^{20}$.

Una consecuencia de esta localización de la extracción y consumo de los recursos fue, a diferencia del Imperio Romano Oriental en el mismo período, el intento de las autoridades califales de asentar tropas sirias en Iraq, en Wāsit. El traspaso de soldados, principales consumidores de los recursos, de zonas que difícilmente podían mantenerlos a áreas con mayores ingresos no era en sí mismo un fenómeno nuevo, ya en la década del 670 se habian mandado tropas de Iraq al Jurāsān por las mismas razones, pero la importancia que tenía el ejército sirio para el gobierno de Damasco, y el hecho de que el traslado había ofrecido a los sirios oportunidades que no podian encontrar en su país, hizo que aumentasen las tensiones entre los ejércitos de ambas regiones; los iraquíes sostenían, por supuesto, que los sirios se estaban entrometiendo en el fay' de los hombres de Iraq ${ }^{21}$.

El conflicto por los ingresos fue, por lo tanto, un aspecto esencial y sistemático de las primera formación estatal islámica. Pero otras consideraciones moderaron esta tensión, en especial la política dinástica llevada a cabo por el Califato y las lealtades regionales o 'tribales' a las que dieron lugar las conquistas de las décadas del 630 y del $640^{22}$.

Un bosquejo de las relaciones de poder en el Califato desde el período de los primeros Omeyas, pasando por la revolución 'Abbāsí del 750, y hasta el siglo $\mathrm{X}$, ilustra un modelo complejo, que cambia y fluctúa constantemente, tejido a partir de intereses creados, tanto económicos como ideológicos, por toda una gama de diferentes agrupaciones sociales, étnicas y religiosas, intereses que

20 Ver KENNFDY, H. «The impact of Muslim rule on the pattern of rural settlement in Syriay, en CANIVEr, P., REY-CoQUAIS, J.P. (eds), La Syrie de Byzance à lIslam, Damasco, 1992, págs. 291-297.

21 Ver St:ABAN, M.A., Islamic bistory A.D. 600-750 (A.H. 132). A new interpretation, Cambridge, 1971, págs. 111,115.

22 Para una detallada historia política de este periodo, veŕ SIIABAN, Islamic bistory A,D. 600750 , paigs. $60-164$. 
hacen imposible imponer y desarrollar una autotidad central efectiva a lo largo de casi todo el período. A esto contribuían diversos factores. En primer lugar, la autoridad de los califas así como la de sus principales consejeros se apoyaba en interpretaciones del Corán y de las Sunna, las tradiciones del Profeta, pero existía un gran número de interpretaciones, a menudo contradictorias, especialmente entre los fragmentados, localizados pero todavía peligrosos grupos de jāriýies, que aparecieron por primera vez a finales de la década de 650 . El término hacia referencia en su orígen a los hombres de las tribus que rechazaton tanto a 'Alī como a Mu'āwiya, y que prefirieron luchar por la independencia de los territorios conquistados que habian ganado, liberados de cualquier forma de régimen central. Durante finales del siglo VII, el término se fue aplicando de forma más generalizada a otros movimientos políticos de motivación ideológica y política hostiles al régimen de Damasco. En segundo lugar, las identidades intensamente regionalizadas de los conquistadores, matizadas a su vez por el crecimiento en el número de los convertidos al Islam entre las poblaciones conquistadas (mawāh), añadió un grado más de complejidad en la política local y en sus relaciones con los califas y sus cortes. Los conflictos «tribales» basados en lo que a menudo eran vagas identidades de parentesco y en torno a intereses económicos creados localmente con respecto a la fay'y a otros ingresos y derechos, hacía del Califato un terreno de lealtades en competencia y potencialmente conflictivas en el que se desataba la guerra y la violencia por cambios aparentemente pequeños de la política en el centro: la más notable fue la tensión entre intereses iraquies y sirios durante el período Omeya, o entre los de Jurāsān e Iraq o al-Ŷazira bajo los 'Abbāsíes, por ejemplo. Y en tercer lugar, la política dinástica que llevó a cabo el clan Omeya-Marwäní y los que se opusieron a su poder, proporcionó más oportunidades para el conflicto dentro de la élite árabe, muy dispersa y multifaccional ${ }^{23}$.

La regionalización de la política fue reforzada por la dependencia de los Omeyas de sus soldados sirios como medio para mantener su autoridad en otros lugares. Esto tuvo repercusiones especialmente graves en Iraq. La identidad de los abl alsäm (dlas gentes de Sirias) puede considerarse como un factor de principal importancia en la vida del Califato Omeya. Parece claro que desde el reinado de 'Abd al-Malik hasta la descomposición del Estado Omeya después de la muerte de Hišăm en el 743, las solidaridades tribales habían sido ampliamente sustituidas, o al menos solapadas, por las regionales. Es difícil asegurar hasta qué punto los sirios se veían a sí mismos como distintos, en contraste directo con los iraquíes u otros grupos claramente regionales, debido a que casi todas las fuentes que describen esta identidad siria lo hacen desde la perspectiva de alguien de fuera. Lo que quizás habtía que destacar es que no son las identidades regionales las que reemplazan las afiliaciones «tribales» adscritas

23 De las numerosas historias detalladas de este périodo, ver en particular SILABAN, M.A., Islamic bistory AD. 600-750, y Islamic bistory. A new interpretation, 2: A.D. 750-1055 (A.H. 132448), Cambridge, 1976; KENNEDY, H., The early Abbasid Calipbate. A political bistory, Londres, 1981.

Hilpania, LVIII/3, núm. 200 (1998) 841-879 
tradicionaimente (como por ejemplo, la Qaysí/Yemení), sino más bien que, a partir de finales del siglo VII, la identidad regional pasa a ser un indicativo tan importante como el parentesco (real o imaginario). Al mismo tiempo, sin embargo, tenemos que reconocer también que estos dos conjuntos de identidades no eran excluyentes entre sí, y que la identidad de un grupo particular puesta de manifiesto por miembros de éste, por sus oponentes, o en las fuentes, depende en gran međída del contexto político y cultural, así como desde qué perspectiva los escritorềs de estas fuentes registraron e interpretaron los hechos en cuestión, y del contexto político y militar de los mismos acontecimientos. Los que querían colocar a la opinión pública en contra del gobierno Omeya, trataron de aprovecharse de las lealtades regionales que, en ese momento, tenian un peso ideológico propio ${ }^{24}$. Sin embargo el renacimiento oportunista de las identidades Qaysí-Yemení en otros contextos ilustra el hecho de que a lo largo del primer período y hasta bien entrada la Baja Edad Media, pervivieron las identidades tradicionales no regionales.

Dada la naturaleza contextual del uso de estas nuevas identidades regionales y de las lealtades y tradiciones que invocaron o inspiraron, no resulta extraño que la segunda o tercera generación tras la conquista musulmana, incluso los nuevos pobladores de Arabia, comenzasen a adquirir este patriotismo local, algo que se desarrolló de forma más temprana entre los Yamaniya de Siria, la mayor parte de cuyos ancestros vivían ya en esta zona antes de la llegada del Islam, tal y como ya he señalado. Los abl al $-S_{a}$ am surgieron claramente como una élite militar, con disciplinadas técnicas de lucha y un alto nivel salarial. Los sirios eran, sin embargo, algo más que un grupo de presión regional entre otros muchos. A la altura del reinado de Hišām habían llegado a formar, de manera real, un ejército profesional al margen del grueso de los musulmanes. Parece que no hay paralelismo con respecto al papel del ejército sirio dentro el Estado bizantino contemporáneo, pues las evidencias sugieren que el ejército de cada zona estaba compuesto por tropas con raíces locales reclutadas en cada localidad, aunque el papel de la fuerzas Opsikion proporciona un lejano paralelismo, y las lealtades e identidades regionales ciertamente tuvieron un lugar destacable. Pero sobre todo, a diferencia del ejército bizantino, sus homónimos en el Califato Omeya nunca tuvieron un estatus legal distintivo, aunque disfrutasen de una posición financiera privilegiada. Hacia finales del período Omeya, la Umma musulmana se dividió entre secciones militares y no militares, un desarrollo que habría de permanecer sorprendentemente estable en las comunidades musulmanas en el Cercano Oriente a lo largo del período preotomano.

La política califal pasó a depender de la necesidad de un compromiso entre estas diversas facciones e intereses opuestos, de la necesidad de obtener suficientes ingresos como para poder mantener algún tipo de ejército controlado

24 Ver, por ejemplo, las tebeliones en las que participan $I$ bn al- $A s^{\prime}$ at, Qutayba ibn Muslim o Zayd ibn Ali, en 700-702, 714-715 y 740 respectivamente. Véase SHABAN, M.A., Islamic bistory A.D: $600-750$, pág. 100 y ss., $128,143-144,179$.

ILipaniá, LVIII/3, núm. 200 (1998) $841-879$ 
de manera centralizada, y de la necesidad de sustentar un nivel mínimo de ortodoxia religiosa que permitiese conservar las lealtades ideológicas de los principales grupos de interés dentro del mundo islámico. Ni siquiera la revolución Abbāsí en el 750, ni los intentos de los califas desde al-Saffāh hasta Hārūn alRašid y sus hijos de reconciliar algunas de estas tensiones (particularmente entre los convertidos y los árabes), lograron mantener una administración central efectiva con una capacidad de control a largo plazo de recursos alejados de las tierras centrales más allá dè un par de generaciones antes de que sucesivos califas necesitaran descubrir nuevos modos de restablecer su poder. Empezando con el establecimiento de una provincia hispánica independiente bajo los últimos Omeyas en la década de los cincuenta y sesenta del siglo VIII, y siguiendo con la creciente independencia de los territorios más lejanos sujetos a regímenes de tendencias ideológicas a menudo hostiles, especialmente en la parte occidental del Norte de África, el Califato empezó a finales del siglo IX a perder cualquier apariencia de unidad política, y a convertirse en una congregación de poderes regionales que debian lealtad ideológica a Bagdad (cuando eran sunníes), o de ninguno de ellos (donde prevalecían diversas formas de shísmo).

Por tanto, la unidad representada por el concepto de Califato a pesar de los breves períodos de tiempo bajo determinados califas en los que llegó a ser casi una realidad política, se convirtió hacia finales del siglo IX en algo meramente teórico: conservó una gran parte de autoridad ideológica-religiosa en las regiones que van desde Siria/Palestina hasta la parte oriental de Irán y Jurāsān; pero el éxito en el Norte de África del shí́smo Ismä̌ili a principios del siglo X, la expansión de los Fatimíes en Egipto a partir de la década de los 60 del mismo siglo, su ocupación de gran parte de Siria, y el desafío directo a Bagdad muestran la fragmentación del mundo islámico tanto ideológica como territorialmente.

En el transcurso de estos acontecimientos deben destacarse algunas cuestiones. En primer lugar, a pesar de la introducción de formas de justicia islámicas y de gobiernos regionales en los territorios conquistados, así como de reformas administrativas tales como la de Abd al-Malik a finales del siglo VII, las relaciones socio-económicas subyacentes entre los agricultores campesinos y los que se apropiaban de los excedentes fueron básicamente las mismas. Sin duda, las políticas califales afectaton a la producción agrícola de diversas maneras, en particular en relación a la atracción de un considerable número de productores agrícolas hacia los centros urbanos, o al incremento de asaltos y saqueos a las caravanas cuando los impuestos y otras imposiciones asociadas comenzaton a ser una pesada carga.

En este contexto socio-político multifaccional y altamente regionalizado no surgió ninguna élite unificada. A diferencia del vecino Imperio Romano oriental (mucho más pequeño geográficamente), existía aquí una serie mucho más compleja de elementos ideológicos y regionales que se solapaban y se intersectaban dentro de una pauta de alianzas y conflictos en permanente cambio. En el nivel de la «institución religiosa», el personal religioso y sus estructuras asociadas, se desarrolló una gran antipatía hacia el gobierno y su servicio junto

Higfania, LVIII/3, núm. 200 (1998) 841-879 
con una tensión entre la administración secular (fiscal y militar) necesaria para los califas, y las tradiciones coránicas en las que se basaba la Umma ${ }^{25}$, la comunidad islámica. Combinado todo ello con las resentidas percepciones de la primera y segunda generación de guerreros tribales en Siria, al-Y̌azira e Iraq, motivadas por los esfuerzos del califa de obtener parte de los ingresos de la conquista, proporcionó un campo fértil para que se desarrollase, bajo la justificación religiosa, la oposición política a cualquier tipo de régimen central o centralizado.

A otro nivel, las formas en las que las tradiciones shiíes evolucionaron proporcionaron también líneas de demarcación ideológicas, políticas y geográficas, obligaron a los califas a aumentar los gastos militares, a buscar nuevas formas de conseguir ingresos, y a formar alianzas políticas oportunistas a corto plazo en un intento de conservar una autoridad política auténtica. La situación se complicaba con las identidades y divisiones tribales y étnicas, creando continuas recombinaciones de aspectos ideológicos, políticos y geográficos que hicieron ineficaces los intentos, por ejemplo, de los primeros califas 'Abbāsíes (desde al-Manșūr hasta Hārūn al-Rašĩd y sus hijos) de establecer una estructura administrativa que fuese efectiva sobre más tierras aparte de las centrales ${ }^{26}$.

El fracaso de los gobernantes de Bagdad a este respecto se pone de manifiesto con la evolución de la igta $a^{a}$. A diferencia del contexto del Imperio tomano Oriental en el siglo XII, en el que se introdujo la misma pronoia como un elemento más para la reconstrucción gradual del poder central, la iqtăt representa la incapacidad del poder central para hacer algo más que reconocer que la situación se le había ido de las manos. Las iqta $\bar{a}^{+}$eran concesiones de ingresos de la tierra, concedidas antes del reinado de al-Mutawakkil (847-861), generalmente a miembros de la farnilia en el poder y a sus favoritos por los servicios prestados, y siempre a corto plazo. Sin embargo, durante el reinado de al-Mutawakkil comenzaron a hacerse concesiones de iqța a los líderes de los principales cuerpos militares asentados en Samarra en un intento de convencerlos para que aceptasen el traspaso de sus fuerzas a territorios lejanos de las regiones políticamente principales de alrededor de la capital; se hicieron concesiones similares a miembros del clan Tāhirí, cuyo poder se había extendido más allá del control político de las provincias orientales de Irán hasta Bagdad, Fars y Samarra, compensándose así su pérdida de posiciones (producto de diversas intrigas políticas inspiradas por el Califa). Dos consecuencias de la política de al-Mutawakkil fueron que, aunque el comandante en jefe del ejército y el oficial jefe de la administración fiscal de las mayores juridicciones fiscales estaban a cargo de sus regiones bajo la supervisión del gobierno cen-

25 Un término acuñado en origen por LYBYER, A.H., The government of the Ottoman empire in the time of Suleiman the Magnificient, Cambridge, Mass, 1913, para contrastarlo con el aparato estatal y sus elementos.

26 SHABAN, M.A., Islamic bistory. A new interpretation, 2, págs, 20-70, proporciona una lúcida interpretación de la política del periodo $c a .770-840$ en el que diversos elementos jugaron un destacado papel. 
tral, la posición potencialmente autónoma que ocupaban dio lugar a la creación de una alianza burocrático-militar que a la larga se convirtió en una amenaza para el gobierno; a su vez, la concesión de $i q t \bar{a}^{\top}$ unida al ejercicio de obligaciones de los oficiales en las provincias fue el primer paso de un proceso en el que el centro iría perdiendo el control efectivo sobre los recursos tanto militares como fiscales en sus propias tierras centrales. En tiempos del califa al-Mu'tamid y de su hermano al-Muwaffaq la política central había devenido en dos facciones polifacéticas pero claramente opuestas: por un lado, los que estaban a favor de la explotación de las regiones en beneficio del gobierno central pero que, para poder mantener un firme control sobre aquéllas, favorecían al mismo tiempo, la utilización de los $i q t a t a ́$, a lo largo del Imperio (mediante la lealtad de los oficiales así designados). Por otro, estaban los que querían evitar la extensión de la iqtá', precisamente por los posibles peligros asociados a ella, y por lo tanto intentaban garantizar salarios regulares y aceptables al ejército para poder así mantener una clara división entre el ejército, y las funciones y puestos administrativos, y distinguir los diversos intereses fiscales de las provincias y el centro.

La iqfắ, administrativo-militar que estaba surgiendo suponía, por tanto, el nombramiento de comandantes militares en muchas regiones en las que tenían completa autoridad sobre todos los asuntos, incluidos los fiscales, a cambio de comprometerse a enviar al tesoro central una cifra fija de los ingresos producidos por la región. A la altura de la década de 880 , y para poder asegurarse unos recursos con los que acabat con una serie de rebeliones en Iraq y más al Oriente, al-Muwaffaq extendió y formalizó la concesión de gran nứmero de iqtă,administrativo-militares. Quizás el ejemplo más claro sea el de Ahmad b. Tülūn, al que se le confirió plena autoridad sobre Egipto a cambio de una contribución regular a Bagdad de rentas egipcias. La administración de Ibn Tülūn fue tan efectiva que añadió el sur de Siria y Palestina a sus dominios, y tuvo la ambición de someter también a su control a los tugūr, o regiones fronterizas del norte de Siria, que era la mejor forma de tener acceso a las rutas de comercio enormemente prósperas de la cuenca oriental mediterránea. Mientras el gobierno de Bagdad todavía estaba intentando reprimir la rebelión Zanŷ al sur de Iraq (que no era, sin embargo, una rebelión esclava, tal y como se sostiene comúnmente) ${ }^{27}$ y se enfrentaba con los rebeldes Saffaríes en el este, las fuetzas Tülūníes intentaron, sin éxito, obligar a las regiones de los tugūr, incluido Tarsus, a que aceptasen su dominio (en parte apoyados por Tos bizantinos). De hecho, aunque los intereses Tülũnies en el comercio podrian satisfacerse mediante la explotación del potencial de los puettos sirios, los intereses económicos de la región de los tugür estaban relacionados con las rutas por tierra desde el este, por tanto, con el gobierno central de Bagdad. Después de algunas luchas, se alcanzó un compromiso a mediados del 880 , por el cual se confirmó la auto-

27 Un idea que se originó con NÖLDEKE, T., aA servile war in the Easbs, en Sketches from eastern bistory, trad. Black, J.S., Edinburgo, 1892, págs. 146-175. Para una versión e interpretación más reciente, ver SHABAN, M.A., Islamic bistory. A nesv interpretation, 2, pág. 100 y sigs.

Hiquania. I.VHII/3, núm. 200 (1998) 841-879 
ridad de los Tülūníes sobre Siria y Palestina, y a cambio aceptaron pagar al erario central cada año una cantidad relativamente modesta. El hermano del califa al-Mu'tamid, al-Muwaffaq, gobernador del imperio en la práctica, intentó al final de su mandato invertir la política que había sido forzado a adoptar hasta el momento, restringiendo la concesión de las iqtă allí donde pudo, aunque frente a una considerable oposición. Un golpe de estado poco después de su muerte en el 892 reemplazó la facción que había apoyado esta política por otra que reivindicaba la línea anterior.

\section{CENTRO Y PERIFERIA}

En realidad, el gobierno central había mantenido un precario control de la situación gracias a la adopción de medidas ad boc adecuadas para la necesidades del momento, que eran modificadas cuando dejaban de ser ventajosas. El liderazgo religioso, bajo la orientación de los hombres de religión, era ejercido nominalmente por los califas, y sirvió en un primer momento para cimentar la hegemonía política califal, reconocidamente frágil si bien aún real; pero la oposición interna a los Omeyas en el período que va desde los años 20 del siglo VIII hasta su caída en el 750 , y la posterior semi-autonomía concedida por Bagdad a sus representantes seculares en casi todas las provincias, hizo fracasar lo que podría haber sido un importante elemento unificador, incluso aunque ya hubiese sido mucho antes cuestionado por una serie de movimientos de oposición. Las medidas a latgo plazo introducidas en la segunda mitad del siglo IX y en la primera del $\mathrm{X}$ tendieron a tener un único objetivo: desarrollar la autoridad central (y sus ingresos), sin tener en cuenta los intereses ideológicos y económicos creados en la región afectada. La creciente tendencia de estas regiones de hacer valer sus propios intereses tuvo, por supuesto, un impacto directo sobre los ingresos centrales, y a su vez sobre su capacidad de movilizar fuerzas efectivas que asegurasen el mantenimiento del control. Cuando en el 892 al-Muafid accedió al poder, se dice que el tesoro central estaba agotado. La igtắ administrativo-militar era el único medio del que disponía el nuevo gobernante, tanto para mantener la apariencia de que existía una autoridad central como para extraer algunos ingresos, y la adopción sistemática de esta forma de mantenimiento de las fuerzas militares y la administración provincial rápidamente dio lugar a la aparición de comandantes provinciales en posesión de una iqta ${ }^{*}$ que fueron capaces de gobernar de manera más o menos independiente, definiendo tanto las demandas de ingresos como la política exterior central. En un intento más de evitar repercusiones fiscales, se introdujo el impuesto agrícola sobre la propiedad de las tierras centrales, con buenos resultados en un primer momento. Pero los líderes militares situados en las provincias reivindicaton las mismas concesiones mientras los dignatarios locales, los líderes tribales, los mercaderes y terratenientes ticos instigaron un gran número de pequeños e importantes levantamientos en un intento de obtener concesiones y privilegios similares. Muchos, especialmente los que tenían un contrato de 
rentas agrícolas, crearon sus propios ejércitos, hasta tal punto que el solapamiento en el personal entre comandantes militares y propietario agricolas dio lugar a la confusión y casi desaparición de la distinción entre los rentistas agrarios y la iqtás.

En este contexto tuvo lugar el aumento de numerosos emires independientes en las provincias medias y periféricas. En las regiones fronterizas, especialmente lós tugür entre Bizancio y el Islam, caudillos locales pudieron establecer regímenes semi-independientes con relativa facilidad, obteniendo reconocimiento de su autoridad desde Bagdad al haberles concedido sus territorios en forma de iqtát. Esto ocurrió en Armenia y en Azerbayán en los años 90 del siglo IX, mientras clanes locales árabes tales como los Hamdaníes se afianzaron de manera similar en el sur y en el oeste. Aunque un califa fuerte como al-Mu'tadid (892-902) fue capaz, a través de vigorosas campañas, de recobrar cierto grado de control central, esto, sin embargo, duró poco. Incluso el destacable éxito de al-Muktafī (902-908), que derrocó a los Tūlūníes de Egipto y restableció la autoridad central (gracias a la hábil explotación de la situación político-militar surgida tras la rebelión Qarmata en la zona desértica sirio-iraquî), fue anulado por la constante sangría de los recursos del centro producto de la frecuente necesidad de imponer la autoridad sobre grupos tales como los Hamdaníes de al-Ŷazira. Los intentos de reforma fiscal fracasaron cuando las demandas del centro chocaron con la oposición a pagar tanto de la población productora como de los líderes locales o de los comandantes militares. Los ataques Fatimíes a Egipto desde su base en Cirenaica representaron una sangría parecida, y no mucho después el Califato tendría que reconocer la autonomía egipcia para combatir tales incursiones, aunque las rentas egipcias continuaron llegando a Bagdad. La incapacidad para ocuparse de las luchas intestinas de los años 20 y 30 del siglo X, el bandorelismo y la secesión local en el sur de Iraq, junto con el fracaso de la reforma fiscal condujeron, en último término, a la creación de un gobierno secular a las órdenes del oficial conocido como Amìr al-umara - comandante en jefe - a cargo de los asuntos tanto militares como fiscales, pero ésto apenas ralentizó el proceso de disolución, pues distintos oficiales militares pugnaban entre sí por conseguir la comandancia suprema. En esta época, por «provincias» se entendía, en realidad, sólo a las regiones de las inmediaciones de Bagdad. La rebelión Daylamí y la extensión de la guerra localizada que le acompañó a partir del 920 , cuyo principal objetivo era la toma de las rutas de comercio que iban desde el Volga, via Bujāra, a través de la parte central y oriental de Irán, hasta llegar a Bagdad, marcó el comienzo de un período de desorden generalizado y de ineficacia por parte del gobierno central. Éste sólo terminó cuando un clan Daylamí, los Būyíes, y sus seguidores, lograron tomar Bagdad, donde establecieron una laxa confederación cuyas distintas partes eran gobernadas por los diversos miembros de la familia Būyí. Aunque se mantuvo la posición del califa, el propio califato estaba en realidad descompuesto $\epsilon_{11}$ sus elementos constitutivos en el este, básados respectivamente en el norte de Irán, Fars y Kirman e Iraq. La toma de Bagdad por los Būyíes en el 945 marcó el verdadero final del Califato como un estado políticamente unificado.

Hippania, LVIII/3, núm. 200 (1998) 841-879 


\section{ESTADOS, RECURSOS Y FORMAS DE REDISTRIBUCION}

La historia de las principales formaciones estatales islámicas desde principios y hasta el período otomano, tal y como se ha ejemplificado aquí de forma muy parcial, es de hecho la historia de una lucha entre tres partes: el gobierno central (o las diversas facciones que competian por el poder central), los (grupos) de interés locales (urbanos, tribales, mercantiles, o una combinación de ellos) y los dirigentes locales que a menudo eran los representantes nominales de los gobernantes, pero que en realidad representaban una élite política fragmentada pero en cualquier caso semi-autónoma. Cada una hacía sus alianzas a corto plazo, a menudo determinadas también por identidades ideológicoreligiosas y por ambiciones político-religiosas (especialmente en el caso de las diversas sectas Ismāîilí del siglo IX en adelante), para poder así alcanzar objetivos a corto plazo. Ninguna fue capaz de conseguir el dominio sin las otras pero la tensión estructural entre los valores percibidos así como entre los intereses económicos objetivos de los otros grupos (en términos de su posición social en las estructuras políticas de apropiación y redistribución de la riqueza) hacía que se librase una constante lucha entre ellos, resuelta por las diferentes regiones sólo de forma temporal con su incorporación a formaciones políticas de distinta connotación (por ejemplo, con el gobieno Fatimí, o de forma más duradera, con los otomanos). Desde luego, tal y como ya han señalado, esto refleja cuestiones tales como el impacto de la ley y tradición islámica tanto sobre la vida política como sobre las relaciones económicas. Del mismo modo, pone de manifiesto las estructuras fuertemente fragmentadas del poder político y las tensiones entre la producción rural y urbana, el tribalismo y los intereses primordiales del centro político. Lo que no refleja es ninguna diferencia estructural entre las formas de producción y apropiación de la riqueza agtaria en forma de impuesto, renta o tributo en las diferentes partes del mundo islámico, o en las regiones de los Balcanes y de Anatolia a finales del mundo tomano oriental.

La concesión de pronoiai a individuos en el período que surge a finales del siglo XI y especialmente del XII en adelante, ha sido una importante fuente de discusión entre los historiadores que intentan determinar qué clase de sociedad era la bizantina. La pronoia era la concesión por el estado del derecho a recibir rentas de unos determinados distritos (por ejemplo, fiscales, o de rentas), o de ciertos estados imperiales y sus arrendatarios, junto con una parte o el total de las rentas e impuestos recaudados por ellos ${ }^{28}$. Estas concesiones las realizaba el gobernante directamente, que representaba al estado en una sentido institucional, y se consideraban la recompensa por los servicios militares prestados. Un asunto parecido es el de la creciente subordinación del campesinado tanto a los terratenientes como a los titulares de pronoiai desde finales del siglo XI en adelante.

28 También tiene otros significados, ascciados generalmente con la esfera religiosa, ver KAZHDAN, A.,et al. (eds.), The Oxford Dictionary of Byzantium, Washington D.C., 1991, págs. 17331734.

Hispania, LVIIJ/3, núm. 200 (1998) 841-879 
Se ha sostenido, por tanto, que estos desarrollos constituían los primeros signos de una proceso de feudalización: hasta la aparición, a finales del siglo XI, de las concesiones militares de pronoia, el estado central había mantenido sus fuerzas sobre la base de los salarios y de la exención fiscal para ciertas categorias de campesinos, para así poder mantener el reclutamiento de unidades mercenarias y de las fuerzas regulares provinciales. El campesinado, predominantemente libre, aunque comenzaba a estar cada vez más sujeto a los expolios y abusos de los grandes terratenientes y los magnates (especialmente en el siglo X) ${ }^{29}$ así como de los arrendatarios de los grandes propietarios, todavía estaba sometido al fisco, o lo que es lo mismo, se le cobraba directamente (aunque algunos propietarios de tierras, particularmente los monásticos o eclesiásticos, estaban exentos por privilegio concedido por determinados emperadores). Con la introducción del sistema de pronoia se inició un proceso de alienación de los derechos fiscales y jurídicos estatales que condujo, en última instancia, a la parcelación y privatización de la apropiación del excedente por parte de la clase gobernante a expensas del estado.

De acuerdo con estos argumentos, el feudalismo se identifica, por tanto, con lo que se considera que son formas institucionales específicas de apropiación del excedente, parecidas a las que tambien se encuentran en las estructuras feudales clásicas del occidente medieval, y que significan un gran cambio con respecto al modo de apropiación del excedente dominante en el período anterior; se considera al pronoia como el equivalente (evolucionado) del feudo: la creciente subordinación de los campesinos libres o semi-libres a la clase magnaticia y a los titulares del pronoia es vista como la vía hacia una población rural semi-servil ${ }^{30}$.

No hay duda de que, a nivel descriptivo, estas instituciones eran parecidas a las de Occidente en muchos aspectos. Tampoco hay duda de que, aunque en teoría fuesen siempre revocables y limitadas, muchas de estas concesiones al final se daban de forma semi-permanente (por varias generaciones, por ejemplo) y tendían a convertirse, por tanto, en propiedad privada de la persona a la que se les otorgaba, especialmente en el caso de las concesiones de términos y de campesinos; los otros tipos de subsidios, de rentas sólamente fiscales, tenían menor tendencia a seguir este camino. Por otra parte, tales concesiones parecen haberse generalizado sólo a partir de mediados del siglo XII como medio de poder mantener los soldados, y muchos de éstas eran muy pequeñas; no se designaban grandes territorios para el mantenimiento de un caballero y a su séquito, sino más bien pequeñas rentas con las que poder mantener a un

29 Morris, R., «The Powerful and the Poot in Tenth-Century Byzantium: Law and Reality), Past and Present, 73, 1976, págs. 3-27.

30 Ver, por ejemplo, Osrogorsky, G., Pour l'bistoire de la fédataté byzantine, Bruselas, 1954; para una valoración más reciente, véase AHRWEILER, H., «La Pronoia à Byzance» en Structures féodales et féodalisme dans 1 Occident méditerranéen $\left(X^{\circ}-X I I^{\circ}\right.$ siêcles), Bilan et perspectives de recherches (= Collection de l'École francaise de Rome, 44), Roma, 1980, págs. 681-689; HoILwEG, A., «Zur Frage der Pronoia in Byzanz", Byzantiniscbs Zeitscbrift, 60, 1967, págs. 288-308.

Hijpania, LVIII/3, núm. 200 (1998) 841-879 
soldado durante un período de tiempo limitado. Es importante destacar que la generalización de esta práctica sucede después de la toma del estado por parte de los Comneno, una de las principales familias de hacendados, y sus aliados, en 1081 .

Pero la pregunta crucial es esta: ¿son estos desarrollos institucionales los signos de la aparición de relaciones de producción tributarias/feudales, es decir, de relaciones de producción diferentes a las que hasta entonces habían prevalecido? ¿Representan de verdad un modo de apropiación del excedente diferente?

La respuesta a estas preguntas debe contestarse, según creo, con una negativa, y por distintas razones. En primer lugar, el modo básico de apropiación del excedente permanece igual que antes: los productores directos, en posesión de sus propiedades, continúan entregando el excedente sobre la base de la coerción extra-económica. La única diferencia es que ahora entregan el excedente, o parte de él, a los recaudadores de rentas de los que han recibido concesiones de pronota. Incluso en los lugares donde sólo se habían concedido rentas, que era la mayor parte de los sitios en primera instancia, esto no cambió. Era el estado recaudador de impuestos el que entregaba la suma adecuada a los titulares de la pronoia. La relación de los campesinos con los medios de producción, la tierra, permaneció igualmente invariable, incluso aunque los campesinos estuviesen cada vez más bajo el dominio de los propietarios estatales y aunque el número de comunidades libres comenzase a descender a partir del siglo $\mathrm{X}^{31}$. En términos económicos, por tanto, no hubo cambio alguno ni en el modo de apropiación del excedente, ni en la relación de los productores primarios con los medios de producción y con sus medios de subsistencia. $\mathrm{Y}$, tal y como hemos visto, estos son dos elementos claves para distinguir un modo de producción de otro, y no parece que se diese ningún cambio de este último.

Lo que sí que cambió fueron las formas institucionales de distribución de los excedentes, ya no a través del estado al aparato estatal, sino directamente a elementos de este aparato, en este caso, a secciones del ejército; y finalmente, a propietarios privados. Y es aquí donde surgió la confusión, lo que los historiadores han querido ver como un modo de apropiación del excedente es, en realidad, simplemente una forma de distribución del excedente, que está determinada en gran medida en el nivel superestructural.

Del mismo modo, lo que otros historiadores han considerado como diferentes modos de apropiación del excedente en un período anterior (impuestos, rentas: propietarios privados con arrendatarios al lado de comunidades campesinas sometidas sólo al impuesto público, o su equivalente, desde el Imperio romano hasta el período medieval bizantino) son, como ya he señalado, simplemente diversas formas institucionales de un mismo modo, en concreto, el

31 Harvey. A., Economic expansion in the Byzantine Empire 900-1200, Cambridge, 1989; y sobre el campesinado bizantino de época más tardía (del siglo XIII en adelante), ver LAIOU. thomadnkis, A.E., Peasant Society in the Late Byzantine Empire. A Social and Demographic Study, Princeton, 1977. 
de la renta feudal o el tributo. La época anterior, desde los siglos V, VI o VII no es, por tanto, un periodo «proto-feudal», en el que dos modos de producción antagonistas, modos de apropiación del excedente, luchasen por el dominio. Más bien al contrario, el modo tributario/feudal dominó de forma clara. La lucha es entre dos formas institucionales de apropiación del excedente, formas que representan los intereses económicos e ideológicos creados por una clase de magnates capaces de independizarse del estado que los había creado, por un lado; y la relativa autonomía del aparato estatal burocrático y centralizado, gobernado por una particular fracción o coalición de éstas procedente de la clase terrateniente, sus clientes, y demás grupos sociales dependientes, por otro. La aparición a partir del siglo IX de estados privados a mayor escala que hasta entonces, con arrendatarios de diversos grados de subordinación, no significa, por consiguiente, que el dominio y la centralidad de un estado en el período precedente (siglos VII y VIII) representase un modo de producción no tributario/feudal (es decir, antiguo o esclavo). Lo que significa es que varios estratos de la pseudo-meritocracia buroctática que gobernaba, que debían su posición y existencia al estado, y que recibían su riqueza excedentaria a través del aparato estatal, constituyeron durante esta época una clase dirigente tributaria/feudal en forma de élite estatal.

Esto es especialmente importante. La diferencia entre estas formas y su evolución representa una de las principales contradicciones estructurales dentro de las formaciones sociales tardorromana y bizantina. Malinterpretarla como una diferencia entre los modos significa no haber entendido la dinámica interna de la formación social y económica bizantina. Lo que en realidad muestra es el desarrollo, a partir del siglo VII, de dos grupos de interés dominantes y antagonistas dentro de la clase dirigente: el que permaneció arraigado dentro del aparato estatal, cuyos intereses ideológicos parecían ser acordes a los del estado; y los que, aunque conservaban (necesatiamente) poderosos intereses creados dentro de las estructuras estatales, consiguieron, en cualquier caso, desarrollar una base económica suficientemente fuerte como para alcanzar cierto grado de independencia con respecto al estado, la cual facilitó una pugna con él por los recursos. Esto no significa que el primero no turviese ni invirtiese tambien en tierras, ni que la demarcación entre los dos grupos no fuese siempre muy fluida ni fuera objeto de una amplia gama de presiones coyunturales, alianzas entre facciones y personalismos individuales. Es importante tener en cuenta esto último porque estos grupos de intereses estaban representados y encarnados precisamente por una práctica social distintiva y las narrativas a través de las cuales ésta se llevaba a cabo. La competición por el poder y la influencia dentro del contexto de la estructura política patrimonial, dominada por las jerarquías formales y el sistema de honor y de estatus del estado imperial, fue un factor importante. Por consiguiente, aunque la riqueza procedente de la tierra jugó, sin duda, un importante papel en la consolidación de la independencia de los magnates, las familias y los individuos también hicieron grandes inversiones en el propio sistema imperial: puestos y sinecuras, «pensiones» estatales, que a menudo alcanzaban considerables ingresos anuales en oro

Hippania, LVIII/3, núm. 200 (1998) 841-879 
y en paños preciosos, así como en atesoramiento de monedas, joyas, vajillas, etc. 'Todos los miembros de clase social dominante, así como sus clientes, invirtieron en esta línea. Aunque muchas familias consolidaron su posición económica por varias generaciones con la adquisición de tierras, parece que un número igualmente amplio poseía poca riqueza procedente de la tierra y eran, por tanto, de forma directa mucho más dependientes del estado, o más especificamente, de un gobernante particular o de la facción palatina del momento. De hecho, se puede describir a estas personas como clientes del propio estado, que formaban, por tanto, un importante grupo de interés en la capital y en el palacio. Debe destacarse que incluso los magnates más independientes, tanto individuales como clanes, dependían de este sistema imperial burocrático para la concesión de títulos, honores, y hasta cierto punto - según la distancia con la capital, las relaciones con la sociedad local y factores similares- del estatus y del pestigio social.

Dentro del complejo conjunto de relaciones sociales, económicas y políticas que representaba esta élite social, con todas las variaciones y matices a los que he hecho referencia, se pueden distinguir, no obstante, dos modos de distribución del excedente, uno basado directamente en la apropiación del excedente a través de la propiedad o del control de la tierra, y el otro, sobre la redistribución de la tiqueza social por mediación del sistema imperial. Estos modos diferentes generaron identidades sociales e intereses económico-políticos que, habiendo convivido durante el siglo VII, finalmente estallaron en un conflicto abierto a finales del $\mathrm{X}$ y en el $\mathrm{XI}^{32}$.

Dentro de las relaciones sociales de producción de Bizancio existía un lucha no entre los diferentes modos de apropiación del excedente, sino más bien en el modo de distribución de éste, dentro de y entre los diferentes elementos de la clase dirigente. Con el desarrollo de la pronoia militar se expresa una fase particular de esta lucha. Y ésta evidencia en sí misma una solución de compromiso a la cuestión del personal y de los recursos asumida por un estado centralizado que ya había empezado a perder control sobre la base de sus recursos en dirección a una élite terrateniente independiente. Los subsidios pronoia, una vez que se hicieron regulares, a partir del siglo XIII, parecieron resolver el problema de financiación del ejército y al mismo tiempo dieron lugar a la continua alienación de los ingresos estatales. También trajeron consigo una creciente alienación de la jurisdicción estatal sobre sus asuntos, y una lenta privatización de los derechos jurídicos del campesinado. El ritmo relativamente lento con el que transcurrió este proceso, y el tamaño limitado de la gran mayoría de las pronoiai militares (el primer ejemplo documentado procede de la segunda década del siglo XII, y se trataba de un subsidio relativamente pequeño destinado al mantenimiento de tres soldados), demuestra que esta institución no era en sí misma el principal factor de alienación de los recursos del estado, tal y como afirmó Ostrogorsky. De hecho, considerando la pérdida de los enormes latifundios

\footnotetext{
32 Cheynet, J.C., Powwoir et contestations d Byzance (963-1210), París, 1990.
} 
territoriales de los hacendados en el centro y en el este de Anatolia tras la ocupación Selŷuquí de estos territorios, el modelo de propiedad de la tierra desde el período de principios de los Comneno y en adelante parece ser que no estaba dominado por estas enormes haciendas. Recientes trabajos sugieren un modelo mucho más complejo de pequeñas y medianas fincas intercaladas con ocasionales grandes propiedades de un importante terrateniente, pero también con una permanencia de pequeños propietarios independientes en muchas zonas. Existian grandes latifundios, pero eran propiedades resultado de la acumulación de tierras de los ricos, y no tenían nada o poco que ver con las concesiones de la pronoia. El principio de reparto de subsidios o pronoiai destinados al mantenimiento de los soldados no parece que afectase mucho a este modelo. En síntesis, el «sistema» de pronoia era sólo un elemento, dentro de toda una serie de desarrollos, que reflejaba la creciente recuperación de la autoridad fiscal del estado, bien como forma de conservar la unidad ideológica o la lealtad política, bien para facilitar el mantenimiento y apoyo de los soldados en las provincias ${ }^{33}$.

Pero aunque afectó el estatus legal de algunos campesinos en determinadas zonas del Imperio, así como a los derechos de los terratenientes que carecían de pronoia, en una evolución que de nuevo pone de manifiesto las antagónicas relaciones de asignación de la riquueza entre el estado y la aristocracia, todos éstos son factores de un nivel secundario, es decir, están relacionados con las formas legales a través de las cuales se realizaba la distribución y redistribución del excedente. En un sentido, son elementos superestructurales o coyunturales, y no reflejan en absoluto ninguno de los cambios fundamentales en el modo de apropiación del excedente o en la relación de los productores con los medios de producción. En otro, funcionan como partes de las relaciones de producción, tal y como ya he apuntado, que expresan, por tanto, la particular configuración de la totalidad de las relaciones de producción que surgen en el contexto de los mecanismos administrativos e institucionales sociales romanos y helenísticos. Dicho de otro modo, los cambios jutídico-legales que hemos señalado representan las formas particulares, específicas históricamente disponibles para esta formación social, y a través de las cual se pueden expresar las cambiantes relaciones de distribución. Lo que se modificaron no eran las relaciones sociales de producción entre las clases, sino las relaciones políticas de distribución entre fracciones dentro de la clase dirigente, y fueron los cambios a este nivel los que tuvieron lugar con las conquistas latinas de principios del siglo XIII, tras la caída de Constantinopla en $1204{ }^{34}$. Debe añadirse que estos cambios fueron acompañados de variaciones en la tasa de explotación de los productores, debido a que cada facción intentó maximizar o garantizar sus ingresos.

33 HARVEY, A., Economic Expansion in the Byzantine Empire, pág. $72 \mathrm{y}$ sigs.

34 Véase la discusión en JACOBY, D., «From Byzantium to Latin Romania: continuity and change», en ARBEL, B., HAMLION, B., JACOBY, D. (eds.), Latin and Greeks in the eastern Mediterranean after 1204, Londres, 1989, págs. 1-44.

Hi.pania, LVIII/3, núm. 200 (1998) 841-879 
El argumento a menudo no da cuenta de que, aunque con frecuencia se puedan haber producido substanciales modificaciones cuantitativas dentro del marco de un conjunto particular de relaciones de producción, esto no tiene porqué implicar un cambio cualitativo, y una transformación del modo de apropiación del excedente. El argumento parecer ser ignorado con frecuencia por los que se oponen a una aplicación más amplia del modo tributario/feudal. En el caso bizantino, la posición del campesinado en relación al estado, a los propietarios privados, y su capacidad para maximizar su independencia jurídica, cambiaron substancialmente en el periodo que va del siglo VI al XV. En la misma época, la relación entre el estado y su clase dirigente también evolucionó, una evolución que estaba relacionada causalmente con la de la posición de la clase productora. El poder sobre la población rural estaba cada vez más en manos de los propietarios privados (incluidos la Iglesia y los monasterios), desde de finales del siglo VIII y, especialmente, a partir del X; $\mathrm{y}$ la competición por la distribución del excedente apropiado tanto por los propietatios como por el estado se fue resolviendo paulatinamente a favor de los primeros.

Así pues, se produjo un clara evolución de las formas jurídicas e institucionales del modo de apropiación del excedente, que expresaba a la vez la principal contradicción dentro de los mecanismos institucionales de recaudación y distribución del excedente disponible para el Imperio romano oriental. Pero la naturaleza esencial de este modo, la extracción de la «tenta feudab» en el sentido de la economía política, no se alteró en absoluto.

Tales variaciones en las relaciones institucionales no pueden atribuirse, por tanto, a un cambio en los modos, a no ser que consideremos que las formas institucionales presentadas en cada estado y formación social particular se hayan constituido de forma arbitraria e independientemente del propio modo de producción. Y esto ignora su función en tanto, precisamente, que elementos de las relaciones de producción que expresan, en una infinidad de formas locales culturalmente determinadas, el modo fundamental de apropiación del excedente. Éstos son una pieza clave en las condiciones de existencia de ese modo de producción, y no pueden ser considerados como algo irrelevante en el funcionamiento y la evolución de éste. No determinan el modo de producción, son sus formas de expresión. Representan las formas de la praxis social a través de la cuales se mantiene y se reproduce.

El desarrollo del estado centralizado bizantino, el grado de relativa autonomía política e institucional alcanzado, y la asignación de «sus» recursos pueden observarse a través del poder que fue capaz de ejercer hasta muy tarde en su historia, invalidando los derechos legales de los propietarios privados que se consideraba que habian acumulado demasiada propiedad; por medio de un proceso conocido como bikanosis («equiparación»), el estado pudo confiscar la tierras que excedían el valor imponible atribuido a un individuo particular o un propietario institucional, y reatribuírselas a sí mismo o a nuevos propietarios privados. Se conoce al menos un ejemplo de esto, que afectó a las supuestamente inalienables tierras de la Iglesia principios del siglo IX; y los manuales 
técnicos fiscales del siglo X al XII dejan constancia de la existencia de esta práctica. A finales del siglo XI, el poder de la clase hacendada era tal, que resultó casi imposible aplicar esta política (excepto en los lugares en los que un gobernante podía aislar a una familia particular), pero aún con todo, a finales del siglo X el emperador Basilio II (976-1025) fue capaz de confiscar tierras de magnates, cuyos dueños suponían una amenaza para el poder imperial ${ }^{35}$.

El estado centralizado continuó existiendo hasta 1453 , y creó una burocracia dependiente tanto de magnates como de los no-magnates. De hecho, el enorme desartollo del sistema ideológico imperial, que exigía un estado imperial centralizado, y que estaba inextricablemente unido a la teología política de la Iglesia Ortodoxa, hizo imposible que se diese algo distinto. Y debe recordarse que, aunque un modo de producción sea una consideración primordialmente abstracta relacionada con las relaciones económicas - fuerzas, medios y relaciones de producción (aunque todas ellas tengan una dimensión social)-una formación social es una forma o variante específica de una combinación de estos modos de estructura económica, y la ideología juega un papel esencial a la hora de determinar cómo funciona y se reproduce, cómo se percibe a sí mismo, y -especialmente en relación con las fuentes literatias y representaciones visuales- cómo pueden construir los historiadores su conocimiento sobre él. La «meritocracia» estatal de los siglos VII y VIII, que se transforma en la clase magnate desde el siglo $\mathrm{X}$ en adelante, estaba ideológicamente ligada a la noción de un estado burocrático y centralizado dirigido por el emperador por designación divina, mucho tiempo después de que la ideología hubiera cesado de representar sus intereses de clase objetivos, y después del desarrollo de intereses y agrupaciones fraccionales dentro de la clase dirigente. Pero al estar la ideologia centrada principalmente en la posición del emperador como representante de Dios en la tierra, más que sobre los distintos conceptos del estado como tal, la representación ideológica del mundo no se consideraba contradictoria dentro de una contexto de cambiantes relaciones de distribución.

\section{¿MODO DE PRODUCCION O FORMACIÓN SOCIAL?}

La transición de las formas sociales, económicas y culturales antiguas a las medievales a principios de la época medieval en la zona este del Mediterráneo adquirió una apariencia muy distinta a la que había adoptado la Europa occidental. Y no sólo se dió en el territorio del Imperio Romano oriental, pues las tierras que se habían perdido a manos del Islam fueron incorporadas a un nuevo sistema estatal, cuyo modelo básico de explotación urbano y agrícola encontraba sus orígenes en su pasado helénico. Estaba igualmente caracterizado

35 Ver OiKONOMIDES, N., «De l'impòt de distribution de qualité à propos du premier cadastre byzantin ( $7^{c}-9^{\mathrm{c}}$ siècle)», Zoornik Radova Vizantoloshieog Instituta, 26, 1987, págs. 9-19, ver 16-17; y Ostrocosky, G., History of the Byzantine State, pág. 306.

Higpania, LVIII/3, nüm 200 (1998) 841-879 
por la existencia de un poder central, por el crecimiento de élites gubernamentales administrativamente localizadas, y por la contradicción entre la propiedad de la tierra y el servicio al estado, aunque las formas sociales y políticas a las que daban expresión fuesen diferentes.

Era en estas contradicciones institucionales y en las variables relaciones entre el estado, su base económica y la clase dominante donde se encontraban los principales mecanismos de limitación impuestos por las relaciones de producción tributarias sobre los estados y, especialmente, sobre su autonomía política. Pues parece claro que es alrededor de las instituciones de apropiación del excedente y de las contradicciones en los métodos de distribución del excedente donde se pueden aislar los cambios y las tensiones de las relaciones socioeconómicas y políticas tanto de Bizancio como del Islam.

Por tanto, igual que en mundo romano oriental, dentro del Imperio islámico se produjeron cambios en las formas de explotación de la tierra y en el comercio (especialmente con la introducción y expansión de la institución del $i q t \bar{a}{ }^{9}$ ), que, aunque representaban cambios substanciales en las relaciones de poder político y en el modo de redistribución del excedente, no implicaron cambios en las relaciones de producción fundamentales, ya que el potencial coercitivo extra-económico legitimado en una serie de prácticas tradicionales y jurídicas continuó dominando las relaciones sociales. Este potencial coercitivo determinó, dentro de la esfera histórico-cultural establecida por las prácticas sociales de las regiones en cuestión, el potencial de desarrollo de los sistemas políticos basados en ellas. Tanto en el contexto bizantino como en el islámico, por tanto, estos desarrollos ilustran las constricciones impuestas por las relaciones de producción tributarias sobre las formas políticas de apropiación y redistribución del excedente ${ }^{36}$.

Los límites impuestos por las relaciones de producción, representados por las estructuras de prácticas sociales, creencias y percepciones a través de las cuales éstos se desarrollan, proporcionan una marco para las diversas posibilidades abiertas a las élites políticas o a los productores para que cambien las condiciones bajo las que operan. La afirmación de que la introducción y adopción generalizada del iqtă "implicó un proceso de "feudalización» es tan poco aceptable como la idea equivalente en la historia bizantina de que la introducción de la pronoia tuvo similares consecuencias para el Imperio Romano Oriental. En ambos casos, una sustancial alienación de los recursos controlados de forma centralizada ha sido equiparada con la devolución de la autoridad política y económica desde el centro a los señores locales típica de ciertas áreas de la Europa occidental a partir del siglo IX. En la medida en que el «feudalismo» de la Europa occidental refleja una devolución similar del poder político y económico, la comparación está justificada; pero si se define el término ufeudalismo"s como un concepto descriptivo histótico con algún valor analítico específico, entonces esto es a lo más que nos lleva esta yuxtaposición descrip-

36 Sobre la iqțata, véase SHABAn, Islamic history. $A$ new interpretation, 2 , págs. $71-88$ con la bibliografia y las fuentes.

Hispania, LVHI/3, núm. 200 (1998) 841-879 
tiva: dadas las posibilidades para la organización política de la apropiación y redistribución de la riqueza en tales sociedades agrarias preindustriales - caracterizadas por una gama de entramados institucionales que van desde el extremo del control central hasta el de la devolución de la redistribución--- esto no resulta sorprendente.

Me parece que la categoría de umodo de producción» tiene poco valor en tales discusiones. Como ya se ha señalado, éste es un recurso heurístico con el que pueden compararse determinados tipos de formaciones sociales históricas. Es, por tanto, un útil punto de referencia en el estudio de los datos primarios, sugiere posibilidades interpretativas, y sobre todo, establece algunos límites teóricos a lo que es una explicación posible o razonable de las relaciones causales que prevalecen en una estructura socio-económica dada. Además, he señalado la importancia de las constricciones a las formas políticas por razón de la naturaleza de las relaciones sociales de producción, especialmente con respecto a los entramados institucionales encargados de la apropiación y la posterior redistribución del excedente.

Aparte de esto, el concepto no puede, sin embargo, ofrecernos más que un poco de orientación detallada, ya que un explicación más completa debe descansar sobre el análisis de sociedades históricas concretas y las diversas formas institucionales a que dan lugar en distintos contextos históricos. Desde luego, no es un obstáculo en la teconstrucción de una tipología de formaciones sociales dominadas por relaciones de producción tributarias, y, de hecho, los rejnos post-romanos de Europa occidental, Bizancio y el Califato ofrecen tres modelos diversos de desarrollos socio-económicos distintos. En otra parte, he examinado de alguna manera diversas formaciones estatales desde la misma perspectiva, en particular, el Imperio Otomano y el Mogol.

Con respecto a esto, me gustaría revisar la insistencia del materialismo histórico tradicional de que forma y función son dos categorías distintas. De hecho, aunque esto pueda ser cierto, debe ser también evidente desde la discusión introductoria que las funciones se desarrollan en forma de praxis social humana, asi que, en este sentido, forma es también función. Sobre esta base es bastante posible, desde luego, aceptar la propuesta de que la dependencia jurídica y la soberanía, al igual que las diversas formas de posesión y propiedad que éstas representan en el registro histótico, no son características marginales, sino que, de hecho, son esenciales en las relaciones sociales de producción tipificadas en la sociedad «feudal» de la Europa occidental. Del mismo modo, la ausencia de propiedad privada de tierras hereditarias en las formaciones sociales islámicas puede considerarse tanto como un resultado histórico de una determinada ideología como un elemento constitutivo en las instituciones políticas que evolucionaron en tales sociedades. Por tanto, uno puede estar de acuerdo con Anderson, por ejemplo, en la medida en que las formas políticas, aunque determinadas por la extracción del excedente, no sólo consolidan las relaciones de producción, sino que además determinan en parte sus condiciones de existencia.

Sin embargo, pesar de esto, parece claro que estas diferencias formales entre las sociedades son variaciones moduladas por la historia, generadas por el 
mismo modelo básico de relaciones de producción que operan en distintos contextos. De hecho, en el caso del Islam tenemos la oportunidad de observar, a través del estudio de su creación y de su evolución político-jurídica, el proceso a través del cual el derecho romano, en el que la propiedad personal privada de la tierra así como de otras formas de posesión se transformó y fue reemplazado por un código islámico en el que la comunidad, y por consiguiente (en la práctica en la mayor parte de los casos, aunque no en todos), el gobernante era el poseedor formal de la propiedad de tierra. El Islam, desde luego, no puso restricciones sobre la capacidad de tener posesiones personales como propiedad privada; e históricamente, tal y como la institución del Waffo donación religiosa ampliamente demuestra, los individuos y las corporaciones institucionales podian burlar con facilidad las restricciones iniciales sobre la herencia así como sobre la posesión de la tierra y sus productos.

A pesar de lo diferentes que tales sociedades pudiesen ser, todavía puede observarse cómo operaban las principales constricciones de las relaciones tributarias, con diversas consecuencias y a través de diferentes formas de acción humana y de los tipos de sociedades a que dan lugar. Lo que seguramente ocurre es que un modo de producción tiene valor sólo en un nivel más amplio de generalización. Para diferenciar y poder trazar la evolución de una formación socioeconómica específica, para entender sus particulares formas institucionales, sus estructuras ideológicas, su producción cultural y vida económica, necesariamente debemos retornar a un análisis mucho más detallado, llevado a cabo en el nivel de la formación social. Así es como, precisamente, nos hemos propuesto analizar formaciones capitalistas específicas; las estructuras de los modos de las relaciones de producción capitalistas muestran, implícitamente o no, la línea general de la investigación y proporcionan cierta orientación de qué clase de interpretación de los diversos tipos de praxis social humana tiende a ser más fructífera. Una comparación de las economías de mercado de la Europa occidental y de los entramados institucionales a través de los cuales ésta funciona, con las de los antiguos países soviéticos, no puede hacerse sobre la base de diferencias en los modos, porque no hay ninguna; más bien, debe apoyarse sobre la discusión de las diversas prácticas y formas estructurales e institucionales en las que el mismo conjunto básico de relaciones de producción da lugar a dos contextos políticos, culturales e históticos completamente diferentes.

\section{IMPUESTO, RENTA Y PROPIEDAD PRIVADA}

Las grandes variaciones en las formas a través de las cuales se expresan las relaciones sociales tributarias en el registro histórico, se hace evidente de muy diferentes maneras. Pero como esto ya ha sido objeto de algunos debates, mencionaré brevemente la cuestión de las formas que adopta el «tributo», al ser éste el principal medio a través del cual se produce la apropiación y redistribución del excedente. En una brillante discusión sobre el desarrollo de la presión fiscal de la Europa occidental en la alta y plena Edad Media, Wickham ha diferen- 
ciado entre tres formas básicas o tipos ${ }^{37}$ : exacciones irregulares y a veces aleatorias en una variedad de formas (productos, trabajo, habilidades, etc.); rentas de la tierra, donde los individuos, y algunas veces los productores, tenían derechos sobre el excedente producido ( $\mathrm{y}$ en ocasiones los productores) a través de una variedad de formas legales (arrendamientos, propiedad privada, concesiones, o una combinación de ellos); y el impuesto, es decir, la extracción regular del excedente a la totalidad de los sujetos, de acuerdo con una serie de medios posibles de cálculo de los ingresos imponibles y de obligación. Existía, desde luego, una continuidad entre los tres tipos, pero no hay duda de que siempre han presentado diversos grados de desartollo de la autoridad politica central, y, por tanto, pueden reflejar tanto la geografía política como la ideología y las formas institucionales a través de las cuales se desarrollan las relaciones sociales. Mi argumento es, sin embargo, que aunque estas tres formas de extracción del excedente pudiesen llevarse a cabo de maneras muy diferentes eran, después de todo, resultado de unas mismas relaciones sociales de producción fundamentales y, por tanto, el nivel «modo de producción» no es ni el adecuado ni es una herramienta analítica a través de la cual podamos diferenciar entre éstos y las formaciones sociales que reflejan.

Una de las principales características del debate sobre qué elementos de la existencia social deben ser considerados estructuralmente relevantes en un modo de producción ha sido una discusión sobre las diferencias en los sistemas jurídicos de cada sociedad, y de las formas en que éstos contribuyen (o no) a la transformación de las relaciones de producción, y cómo. Por consiguiente, la posición dominante entre los materialistas históricos sostiene que la trayectoria evolutiva de la propiedad privada de la tierra en el occidente medieval se distingue de la de otras regiones. Partiendo de la existencia de una absoluta propiedad privada de la tierra a lo largo del mundo romano tardío, y desde entonces en Bizancio, en la Europa occidental evolucionó una forma de propiedad privada condicional (tierras «(regias», «estatales» o «tribales» concedidas a un individuo sobre una base contractual, como recompensa por sus ingresos y sus servicios), que finalmente se convirtió, en diferentes grados en las distintas regiones, en propiedad privada absoluta facilitando, por tanto, la expropiación de los derechos y la tierras de los productores campesinos, la creación de un mercado libre de la tierra, y las posibilidades de una producción agraria capitalista. En el contexto histórico adecuado, tal y como correctamente ha puesto Anderson, esta combinación de desarrollos hizo posible la expansión y generalización de las relaciones capitalistas de producción, primero dentro del sistema anterior de relaciones de producción, y después teemplazándolo y marginảndolo ${ }^{38}$.

37 WICKHAM, C.J., «Lineages of western European taxation, 1000-1200", en SÁNCHEZ, M. y Furió, A., (eds.), Actes, Collogui Corona, Municipize i fiscalitat a la baixa Edat Mitjana, Llerida, 1997 , pp. $25-42$, esp. $26-27$.

${ }_{38}$ Ver el excelente estudio de ANDERson, P., Lineages of the absolutist state, paigs. 424-426.

Hipunia, LVIII/3, núm. 200 (1998) 841-879 


\begin{abstract}
Ahora bien, nadie puede negar que la divergencias en el desarrollo que tuvieron lugar dentro y entre las antiguas provincias del mundo romano, y que también estaban basadas en la evolución histórica regionalizada de esas zonas, estaban en la raíz de estas diferencias. Del mismo modo, debe quedar claro que, incluso aunque las formas institucionales de las relaciones de producción a lo largo del mundo romano estuviesen representadas por una amplía gama de variantes localmente moldeadas, era básicamente dominante el mismo conjunto de relaciones de producción. Así es que podemos preguntar razonablemente qué aspecto de estas relaciones de producción cambió con, por ejemplo, la llegada de los Germanos en el oeste, o el Islam en el este. Desde luego, surgen instituciones nuevas o diferentes, junto con novedosos modos de hacer las cosas. Se desarrollan sistemas ideológicos nuevos, que incorporan antiguas tradiciones como introducen novedades. Los sistemas monoteístas, en particular, empiezan a determinar, en mayor medida que hasta entonces, el universo moral y cultural en el que habitan los individuos y los grupos, afectando también, por tanto, las posibilidades de acción social de éstos. Hasta este punto, es razonable afirmar también que las ideas y las creencias se incorporan de forma dialéctica a la constitución de la praxis social y éstas también pueden, por tanto, ser clasificadas funcionalmente como elementos de las relaciones sociales de producción, bien como elementos constitutivos, o bien en términos
\end{abstract} de sus condiciones de existencia y reproducción social.

La dificultad aquí es, desde luego, que en la medida en que esto es cierto de forma descriptiva, cualquier forma de praxis social puede considerarse, por tanto, como una actividad representativa a través de la cual se desarrollan y se ponen en práctica las relaciones sociales de producción. ¿Cómo podemos distinguir los aspectos del ser social, para así determinar dónde radican las diferencias entre sistemas distintos y excluyentes entre sip. Construir un modelo de modo de producción con estos matices conlleva el problema de qué aspectos de la superestructura legal/cultural se consideran estructurales y cuáles no. La respuesta propuesta por Anderson, que consiste en rastrear los rasgos que parecen ser la fuente de las diferencias en sus orígenes, y construir con ellas la estructura de las relaciones de producción, se ha mostrado que es inadecuada, necesariamente dependiente de un determinismo teleológico y genético. La alternativa es concluir que, a pesar de lo artificial que pueda ser la distinción analítica, lo más sencillo es distinguir un sistema de otro sobre la base de un estudio de los modos en que se produce la apropiación del excedente, y las formas en la que se combinan los medios de producción con la mano de obra.

Ahora bien, se ha señalado que esto supone excluir los aspectos «superestructurales), reduciendo así las diferencias entre los sistemas al mínimo denominador común, bajo criterios puramente «económicos» y perdiendo, por tanto, los matices que aportan los diferentes efectos de la praxis social sobre estos elementos básicos ${ }^{39}$. Nos quedamos, en realidad, en un impasse: o reducimos el modo de producción a las

39 ANDERson, P., Lineages of the absolutist state, pág. 402 y sig's., 423 y sigs.; Asrarim, C., «La discutida universalidad del sistema tributarion, Studia historica: Historia Medieval, 12, 1994, págs. 191-201, ver esp. págs. 195-197. 
relaciones económicas fundamentales, algo que al ser tan general y universal no proporciona elementos distintivos de muchas de las formaciones sociales precapitalistas; o tomamos en cuenta una varidad de elementos "superestructurales", pero sin saber qué elementos son de mayor importancia estructural en las sociedades que se comparan. Tenemos en cuenta la diversidad histórica, pero nos arriesgamos a multiplicar ad infinitum el número de modos de producción bajo criterios puramente subjetivos. La primera aproximación aparentemente no proporciona forma de diferenciar las sociedades; la segunda, aporta demasiadas.

¿No debería esto, en realidad, dar lugar a una radical reevaluación de lo que consideramos que debe lograr un modelo de modo de producción?. Desde luego, esto proporciona un marco general en el que la naturaleza de los constreñimientos sobre la forma de apropiación y redistribución del excedente es el centro del análisis de las formas políticas y sociales. Esto, por tanto, proporciona un medio para diferenciar las sociedades dominadas por un conjunto de relaciones de producción o por otro; y aporta, por consiguiente, la posibilidad de comparar los diferentes efectos de los límites estructurales generados dentro de cada uno. Proporciona, de igual forma, cierta orientación de las posibilidades de transformación, dentro de cada contex to histórico dado, de las relaciones de producción. La comparación de las relaciones de producción capitalistas con las no capitalistas, o las esclavas con las tributarias, tanto entre formaciones sociales diferentes como dentro de una sola, nos proporciona, por tanto, perspectivas claves del potencial relativo de cada una en conflicto o en contradicción con la otra.

Pero esto no explica las diferencias entre formaciones sociales dominadas por el mismo modo de producción. Y es aquí donde realmente se centra el debate. Pues me parece que los historiadores que prefieren una definición de modo de producción más específica y matizada, lo que en realidad quieren es una teoria explicativa que dé prioridad a las variantes europeas de relaciones tributarias (fundamentalmente porque éstas generan relaciones de producción capitalistas y, en menor medida, porque los orígenes del capitalismo eran el principal objetivo de estudio de Marx). Pero si hacemos esto, estamos ignorando gran parte del espectro de sociedades históricas; en realidad, a menos que aceptemos el tipo de teleología genética implícita en la investigación de Anderson de las causas de las particuliaridades europeas, no estamos creando una herramienta útil para realizar comparaciones más amplias, a no ser que adoptemos, precisamente, la estrategia de identificar los modos de producción a través de sus distintas formas de expresión.

Lo que en realidad deberíamos buscar no es uno o unos modos de produccción desconocidos hasta el momento, que explicarian porqué las formaciones sociales y los sistemas estatales europeos, asiáticos, indios o americanos adoptaron apariencias tan diversas sino, más bien, una tipología de sociedades caracterizadas por el predominio de un determinado modo, que tenga en cuenta los diferentes sistemas ideológicos religiosos, los diversos modelos de distribución del poder social, los distintos tipos de estrategias societales, en niveles diferentes o en distintos segmentos de la formación social en cuestión,

Higtomia, I.VIIt/3, núm. $200(1998)$ 841-87) 
en la que se reconozca la complejidad y la pluralidad funcional, y en la que las asunciones sobre la validez predictiva de la tipología sea irrelevante. Tanto el trabajo de Michael Mann como el de W.G. Runciman ofrecen algunas aproximaciones posibles, materialistas, pero explicitamente a favor del pluralismo causal, en las que se da por dada la diversidad de causas y efectos de un contexto histórico-cultural o de otro, ya sea geográfica como cronológicamente.

Ahora bien, ya he señalado en la introducción a esta colección que, aunque las relaciones de producción creen las precondiciones para su propia transformación y disolución, las posibilidades para tales transformaciones son inmanentes. En cualquier formación social histórica, sean cual sean las relaciones de producción dominantes, son los contextos especificos, generados por coyunturas especificas en el tiempo y en el espacio, en otras palabras, momentos particulares en los que se desarrollan, en términos de praxis social, las discrepancias entre fuerzas y relaciones de producción, los que conducen a transformaciones en los modos. Éstas son sólo predecibles en un sentido general, limitadas por las condiciones de existencia de conjuntos de relaciones de producción dados y por formas históricamente específicas de sus contradicciones internas. La transformación no es, por lo tanto, una consecuencia inevitable del paso del tiempo, pero es siempre una posibilidad, bajo determinados conjuntos de condiciones. Lo que tenemos que aclarar en el caso del surgimiento del capitalismo a partir de las relaciones de producción feudales en la Europa occidental es, por tanto, los conjuntos de circunstancias especificas, y sus trayectorias, orígenes y formas individuales e inicialmente desconectadas, que facilitan las transformaciones. Intentar encontrar un modo clave para esta cuestión, en términos de «inevitalidades» (si x es a y, entonces se dará z), es una pérdida de tiempo. Esto no significa que los principales supuestos, tales como las posibles consecuencias de la contradicción entre fuerzas productivas y telaciones de producción, se conviertan en algo irrelevante. Es sólo que sus efectos deben ser considerados como contingentes, y no como inevitables.

Esto representa, desde luego, un radical distanciamiento de cierto materialismo histórico «tradicional». Pero ello no resta valor a la creación de modelos de modos de producción siguiendo las líneas que yo asumo; más bien al contrario, creo que hay que restablecer sólo la clase de distinción entre teoría general e investigación empírica y análisis elegida por el propia Marx. Mantengo que los historiadores quieren diferenciar un modo feudal en Occidente y, en menor medida, en la Europa de este (y en unos pocos sitios más) de otros modos, porque es una forma más directa y simple de explicar la preeminencia occidental en la evolución de las relaciones capitalistas. Yo sostengo que esta es la agenda oculta del deseo de mantener una diferencia entre feudalismo y otras formaciones económicas precapitalistas basadas en la clase social como si fuesen modos distintos, y que la necesidad de identificar las formas institucionales a través de las cuales se desarrollan las relaciones de producción en tanto que modos de producción distintos es una consecuencia inevitable de ello.

Traducción

Nuria Garia Atienz̧a

Hipastia, LVIII/3, nưm. 200 (1998) 841-870) 